\title{
Homonationalisme og biopolitik
}

Af Jasbir Puar

"Folk er nu på vej ud af skabet hvad angår ordet imperium", sagde den konservative klummeskribent Charles Krauthammer. "Faktum er, at intet land i verdenshistorien har været kulturelt, økonomisk, teknologisk og militært dominerende siden Romerriget." Komme-ud-metaforen er slående og del af en større trend med at appropriere progressive bevægelsers sprogbrug til gavn for imperiet. Hvor er det forrykt at bruge gay pride-bevægelsens sprog til at beskrive en militærmagt, som kræver, at dens soldater bliver i skabet.

- Amy Kaplan, "Violent Belongings and the Question of Empire Today"

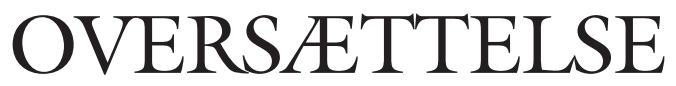

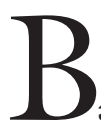

åde Krauthammer

og hans kritiker, forsker i amerikansk kultur Amy Kaplan, fremhæver sammensmeltningen af amerikansk seksualitet og politik. ${ }^{1}$ "Spring-ud"-metaforen, som Kaplan senere påpeger at amerikanske neokonservative bruger uafbrudt til at udbrede en stadig større fortrolighed ved ideen om USA som et imperium, er bemærkelsesværdig, både på grund af sin approprierende udbredelse, men også på grund af, hvad approprieringen kategoriserer. På den ene side markerer sammensmeltningen et kulturelt øjeblik for en national inklusion af homoseksualitet, hvilket medfører en særlig slags parallel mulighed for den frigjorte nation og den frigjorte queer person. Denne anvendelse af homofrigørelsens lingua franca peger på, at det amerikanske imperiums frigørelse fra 'skabet' - et imperium som allerede er kendt men skjult - vil og bør resultere i stolthed, et stolt amerikansk imperium. I denne skarpsindige tekst udpeger Kaplan de nødvendige udeladelser i Krauthammers 
erklæring, mens hun desværre selv fremkalder andre udviskninger. Et hurtigt blik på demografien kunne indikere at de befolkningsgrupper, der med størst sandsynlighed bliver gennet tilbage i skabet af "Don't Ask, Don't Tell"-loven, på baggrund af deres uforholdsmæssigt store repræsentation i det amerikanske militær, er ikke-hvide mænd og kvinder. ${ }^{2}$ Derfor antyder nationen muligvis implicit, at ethvert tilhørsforhold til subjekter med ikke-normativ seksuel orientering er skarpt indskrænket af "et militær, som kræver, at dets soldater bliver i skabet". Dette forbehold er indirekte formet af racisme, idet der optegnes en afgrænsning, hvor de mindst velkomne deltagere i denne nationale stolthed er ikke-hvide queers. I denne genvinding af exceptionalisme fremfører både Krauthammer og Kapland en problematisk bekræftelse af den teleologiske investering i spring-ud-historier og narrativer om at "blive i skabet", som længe har været kritiseret af poststrukturalistiske teoretikere for at indskrive og bekræfte privilegerede og liberale (hvide) homoseksuelle og queer subjekter.

National anerkendelse og inklusion, som her kommer til udtryk gennem annekteringen af en homoseksuel jargon, afhænger af adskillelsen og diskvalificeringen af raciale og seksuelle andre fra det nationale billedsprog. Inden for denne dynamik eksisterer en form for seksuel exceptionalisme - fremkomsten af en national homoseksualitet, eller det som jeg kalder "homonationalisme" - som svarer til en springen ud for det amerikanske imperiums exceptionalisme. Denne form for homoseksualitet fungerer desuden som et regulerende manuskript for ikke blot normativ homoidentitet, queeridentitet eller homoseksualitet, men også for raciale og nationale normer, som forstærker disse seksuelle subjekter. Der findes en forpligtigelse i den globale hvidhedsdominans, som er indblandet $\mathrm{i}$ udbredelsen af USA som imperium, såvel som en alliance mellem denne udbredelse og denne form for homoseksualitet. Den flygtige godkendelse af et nationalt homoseksuelt subjekt bliver ikke kun muliggjort gennem en udbredelse af seksuelle-raciale subjekter, der uundgåeligt vil falde udenfor denne godkendelses snævre ramme for, hvad der er acceptabelt, hvilket andre også har påpeget, men også særligt gennem den samtidige skabelse og fornægtelse af befolkninger af seksuelle-raciale andre, som slet ikke behøver ansøge om godkendelse.

I det følgende udforsker jeg disse tre overlappende manifestationer - seksuel exceptionalisme, queer som regulerende og hvidhedens dominans - samt deres relation til produktionen af terrorist- og statsborgerkroppe. Mit mål er at præsentere et fleksibelt portræt, som udviser opmærksomhed for hvordan, hvorfor og hvor disse tråde støder sammen og hvor de væves sammen, for at undgå et mekanisk forklarende greb, der kan dække alle disse komponenter. Det bemærkelsesværdige ved fænomenet, som jeg kalder "amerikansk seksuel exceptionalisme" fortællingen om den succesfulde håndtering af liv i forhold til et folk - er, at en exceptionel form for national heteronormativitet nu slås sammen med en exceptionel form for national homonormativitet, med andre ord homonationalisme. I fællesskab fortsætter eller udvikler de projektet om amerikansk nationalisme og en udvidelse af imperiet til at omfatte krigen mod terror. Det moralske regelsæt har ændret sig på en sådan måde, at homoseksualitet ikke længere per definition er ekskluderet fra nationale formationer. Jeg afdækker implicitte former for regulering af queer subjekter, former som er transcendente, sekulære eller på anden vis eksemplariske som værende modstandsdygtige, og jeg åbner op for spørgsmålet om queer re/produktion og regenerering og dennes bidrag til projektet om optimering af liv. Hvidhedens dominans er en beskrivelse af biopolitik fremsat af Rey Chow, som sammenkæder brutaliteten i den liberale implementering af diversitet og multikulturalisme med alibiet om "valoriseringen af liv", der så tillader hæmningsløs udnyttelse af 
netop det subjekt, som i første omgang var inkluderet i diversitetsdiskurser. Jeg belyser, hvordan disse tre tilgange til seksualitetsstudier, når man ser dem i sammenhæng, giver anledning til en dybdegående genlæsning af biopolitik i forhold til queerhed såvel som hvor uløseligt sammenfiltret queerhed og biopolitiske organiseringer af liv og død.

\section{AMERIKANSK SEKSUEL EXCEPTIONALISME}

En kortlægning af hvordan homoseksuelle foldes ind $\mathrm{i}$ den reproduktive valorisering af livet - af teknologier af liv - inkluderer den nyligt opståede "seksuelt exceptionelle" amerikanske borger, som kan være både heteroseksuel og andet, en tilblivelse som jeg kalder "amerikansk seksuel exceptionalisme". Paradoksalt nok signalerer exceptionalisme både en forskel fra (at være uens, ulig) såvel som en excellence (af forrang, overlegenhed), hvilket tyder på en afstand fra hidtidige herredømmer af lineære teleologier om fremgang. Exceptionalisme referer både til specifikke diskurser, der gentagende producerer USA som en exceptionel nationalstat, og til Giorgio Agambens teoretisering over den sanktionerede og naturaliserede ligegyldighed i forhold til statens retslige og politiske beføjelser under nationale kriser, en "exceptionel tilstand" eller undtagelsestilstand, som bruges til at retfærdiggøre statens ekstreme metoder. (Agamben 2005). ${ }^{1}$ I dette projekt henvender denne exceptionalismes dobbelthed sig både til muslimske og sikh "terrorist"-kropsligheder såvel som homo-

1. Note fra oversætteren: Ordet exception har på engelsk en dobbeltbetydning. Når Puar benytter begrebet "the state of exception", kan der således både være tale om betydningen undtagelsestilstand og om, hvordan USA nyder en exceptionel position som stat. seksuelle patrioter. Skandalen om seksuel tortur i Abu Ghraib-fængslet er et informativt eksempel på samspillet mellem undtagelse og exceptionalisme, hvorved én befolknings død viger tilbage for en værdisætning og valorisering af en anden befolknings liv, der så triumferer på bekostning af den første befolkning. Denne dobbelte implementering af undtagelse og exceptionalisme vender torturens negative valens til den positive valorisering af (amerikanske) liv, hvilket vil sige tortur under dække af at maksimere og optimere liv.

Eftersom den amerikanske nationalstat producerer undtagelsesnarrativer via kampen mod terror, må den midlertidigt suspendere sit heteronormativt antagede frellesskab for at konsolidere nationalfølelse og konsensus igennem anerkendelsen og inkorporeringen af nogle, men ikke alle eller de fleste, homoseksuelle subjekter. Fantasien om det permanente ved denne suspendering er det, der driver produktionen af exceptionalisme i et narrativ, der er historisk og politisk stærkt knyttet til skabelsen af den amerikanske nationalstat. Undtagelsen og det exceptionelle arbejder således i tandem; undtagelsestilstanden hjemsøger udbredelsen af exceptionelle nationale subjekter, hvilket har ligheder med Derridas 'hauntology', hvor spøgelser, de fraværende og samtidig tilstedeværende væsner, indgyder ontologi (med) en forskel (Derrida 1994).

Via den transnationale produktion af terroristkropsligheder opnår homoseksuelle subjekter, som har begrænsede juridiske rettigheder inden for en civil amerikansk sammenhæng, betydelig repræsentativ valuta, når de placeres på den globale scene i kampen mod terror. På grund af heteroseksualitetens nødvendige konstituerende faktor for national identitet har homoseksuelle subjekters "lovløse" status i relation til staten længe været af teoretisk interesse for feministiske, postkoloniale og queer teoretikere. Denne lovløse status formidles via etableringen af den homoseksuelle forbruger, som marketingsansvarlige jagtede i 
1980'erne og 1990'erne, da de hævdede, at barnløse homoseksuelle havde en enorm disponibel indkomst, såvel som via juridiske forbedringer af borgerrettighederne, såsom den udbredte fejring af sagen Lawrence and Garner v. Texas, der betød en afskaffelse af sodomilove. Ved at fremhæve kredsløb af homoseksuel nationalisme påpeger jeg, at nogle homoseksuelle subjekter er medskyldige i etableringen af heteroseksuelle nationalistiske formationer i stedet for $\mathrm{i}$ sagens natur eller automatisk at være ekskluderet fra eller imod dem. Desuden forekommer der en mere skadelig beboelse af homoseksuel exceptionalisme i form af en iscenesættelse af amerikansk nationalisme via praktisering af seksuel andetgørelse, hvilket exceptionaliserer amerikanske homoseksuelle identiteter i modsætning til orientalistiske konstruktioner af "muslimsk seksualitet". Denne diskurs fungerer i kraft af transnationale forskydninger, som væver rum for kulturelt statsborgerskab i USA sammen med homoseksuelle subjekter og samtidig sikrer nationalistiske interesser på et globalt plan. I nogle tilfælde er disse narrativer eksplicitte, som for eksempel i efterspillet af offentliggørelsen af Abu Ghraib-billederne, hvor kravet om exceptionalisme gav genlyd på mange planer for amerikanske statsborger-subjekter: moralsk, seksuelt, kulturelt, "patriotisk". Denne overlapning af lag af amerikansk exceptionalisme bærer i højere og højere grad præg af og bliver båret på vej af homoseksuelle kroppe, hvilket vil sige igennem homonationalisme.

Hvad der er nyt her er hverken begrebet exceptionalisme eller den kønsexceptionalisme, som har domineret historien om den vestlige feministiske teori og aktivisme. Nutidige former for exceptionalisme fungerer eller udvikles ved at hæfte sig eller blive hæftet på ikke-heteroseksuelle, homonormative subjekter. Exceptionalisme bruges ikke til at markere et brud med historiske retninger eller en påstand om enkeltstående nyhed. Exceptionalisme peger derimod på narrativer om fortræffelighed; fortræffelig nationalisme, en proces, hvor en nationalbefolkning kommer til at tro på sin egen overlegenhed og sin egen singularitet, "klistret sammen" med forskellige subjekter, som Sara Ahmed ville sige det (Ahmed 2004). Diskurser om amerikansk exceptionalisme er indlejret i historien om skabelsen af den amerikanske nationalstat fra tidlige immigrationsnarrativer til koldtidsideologier og til terrorismens fremkomst. Disse narrativer om, hvor central exceptionalisme er for tilblivelsen af USA, indikerer, at indoktrinering à la exceptionalisme er en del af disciplineringen af den amerikanske borger (som det meget vel er tilfældet for enhver nationalistisk tilblivelse). ${ }^{3}$ Debatter om amerikansk exceptionalisme har typisk benyttet sig af kriterier så forskellige som blandt andre kunstnerisk udtryk, æstetisk produktion (litterært og kulturelt), socialt og politisk liv, immigrationshistorie, liberalt demokrati, og industrialisering og kapitalistiske mønstre. (For et overblik se Kammen 1993; Rauchway 2002; Zinn 2005). Diskussioner om amerikansk exceptionalisme involverer dog sjældent emner som køn og seksualitet. Hvor akademikere de sidste fyrre år har kritiseret feministiske praksisser og teoriretninger, som eksplicit eller implicit fremmer konsolide- ringen af amerikansk nationalisme, er der nu i kølvandet på dette en voksende gruppe, som gransker queer praksisser og teoriret- ninger for lignende tendenser. Former for amerikansk køns- og (hetero)seksuel excep- tionalisme dukker op fra angiveligt pro- gressive steder ved hjælp af feministiske konstruktioner af "andre" kvinder, især via konstruktionen af "den tredje verdens kvinde" (Mohanty 1988).

Inderpal Grewal argumenterer eksempelvis imod feministers naturalisering af menneskerettighedernes rammer ved at pointere, hvordan USA rutinemæssigt positionerer sig selv som "hjemstedet for autoritær fordømmelse" af brud på menneskerettighederne $i$ andre dele af verden, mens misbrug indenfor egne grænser ignoreres. Grewal henviser til den amerikanske exceptionalisme, 
som nu er en form for påkrævet sund fornuft blandt mange feminismer inden for amerikanske offentlige kulturer:

Moralsk overlegenhed er blevet en del af nyere global feminisme, hvilket konstruerer amerikanske kvinder som de 'undertrykte kvinders' frelsere (Grewal 2005: 150).

Det, at vestlige feminister på det seneste har taget sager om afghanske og irakiske kvinder og muslimske kvinder generelt til sig, har genereret mange former for amerikansk kønsexceptionalisme. Kønsexceptionalisme fungerer som en missionerende diskurs, der vil redde muslimske kvinder fra deres undertrykkende mandlige modstykker. Det fungerer også ved at foreslå, at muslimske kvinder, i modsætning til kvinder i USA, i sidste ende er umulige at redde. Derudover hentyder disse exceptionalismediskurser på listig vis til de muslimske kvinders ikkeredbare natur, der betyder, at ikke engang deres egne feminister formår at redde dem, hvilket omvendt positionerer den amerikanske feminist som det feministiske subjekt par excellence. 4

Et aktuelt eksempel er fra interaktionen mellem Revolutionary Association of the Women of Afghanistan (RAWA) og Feminist Majority Foundation, som endte med at Feminist Majority Foundation blev beskyldt for at have approprieret og udvisket RAWAs indsats. I et brev dateret 20. april 2012 fordømmes Feminist Majority Foundations manglende anerkendelse af RAWAs 25-årige tilstedeværelse i Afghanistan (faktisk blev RAWA slet ikke nævnt i udlægningen) samt udlægningen af, hvordan Feminist Majority Foundation spillede "en ledende rolle $\mathrm{i}$ 'befrielsen' af de afghanske kvinder", der giver indtryk af, at foreningen "på helt egen hånd befriede de afghanske kvinder fra en undertrykkelse, som startede og sluttede med Taleban". RAWA kalder Feminist Majority Foundation for "hegemonisk, USA-centrisk feminisme drevet af egoer og virksomheder" og pointerer, at RAWA selv har "en historie som er længere end Feminist Majority Foundation og citerer desuden adskillige tilfælde, hvor Feminist Majority Foundation har slettet RAWAs politiske organisering. RAWA kritiserer ligeledes Feminist Majority Foundation for at undlade at nævne Den Nordlige Alliances misbrug af kvinder, som til tider var grovere end de uhyrligheder, som Taliban begik. RAWA bemærker:

I forsøget på at opnå politisk og økonomisk magt i USA træder Feminist Majority Foundation meget forsigtigt for ikke at gøre de amerikanske politiske magter vrede (Brown 2002; Miller 2002).

Disse "hegemoniske USA-centriske" feminister, som var betagede af de afghanske kvinders kår under Talibans styre, inkluderede Feminist Majority Foundation, som søsatte "vores kampagne for at stoppe kønsapartheid i Afghanistan" i 1996.5 Denne kampagne førte formentlig til fetishhandelsvarer såsom Eve Enslers v-Day velg $\varnothing$ renhedskampagne, som med sin "hyldest til afghanske kvinder" skrev monologen "Under Burkaen", der blev opført af Oprah Winfrey på New Yorks største stadion, den helt udsolgte Madison Square Garden, i februar 2001.6 Arrangementet lancerede også salget af burkastof, som skulle bæres på brystet for at vise solidaritet med afghanske kvinder gennem approprieringen af et "muslimsk" klædestykke. Selvom disse former for celebrity-feminisme kan give os kortvarig hånende fornøjelse, er de en integreret del af den offentlige feministiske kultur og bør ikke opfattes som banale. Deres dagsorden er forholdsvis gunstig for seriøse liberale feminister i USA, såsom dem i Feminist Majority Foundation, og i disse tider med professionaliseret feminisme afslører disse angiveligt divergerende grupper deres overlapning via forskellige former for kommer- cialisering. Disse feminister, som allerede havde udpeget islamistisk fundamentalisme som den største voldelige trussel mod 
kvinder, var fuldstændig klar til at drage fordel af de missionerende diskurser, som rungede efter 11. september. På trods af deres aktive modstand mod invasionen af Afghanistan blev de fanget $i$ et medløbende narrativ om amerikansk exceptionalisme i forbindelse med at fjerne Taliban fra magten. 7 Som Drucilla Cornell bemærker, så tvinger Feminist Majority Foundations udeblevne reaktion, da Taliban blev erstattet med Den Nordlige Alliance, os til

at stille spørgsmål ved, om ikke den amerikanske regerings humanitære interventionsdiskurs muligvis fungerede som en særlig kynisk indsats for at få de amerikanske feminister på sin side i forsøget på at afgrænse, hvad der skal defineres som overtrædelser af menneskerettighederne - for at gøre Feminist Majority Foundation til et ideologisk redskab til at delegitimere de politiske krav om at rette op på overtrædelsen af menneskerettighederne (Cornell 2004).

Grundlæggende antyder Cornell altså, at amerikanske mainstream feminister byttede RAWAs modstand mod strafferetslige statslove, som straffer kvinder, der nægter at bære burka (men ikke modstand mod kvinder, der bærer burka, hvilket er en væsentlig forskel), til fordel for det jublende mediecirkus, der løb løbsk i de amerikanske medier efter den "succesfulde" invasion af Afghanistan. ${ }^{8}$ I den grad under burkaen. For en sidste kommentar i denne sag bør man bemærke Gayatri Chakravorty Spivaks observation: "Hver eneste gang vil vi se narrativet om klassemobilitet." For at gøre enhver oprindelig positionering af RAWA mere kompleks skriver hun:

Det er middelklassens tilblivelse, der skaber muligheden for den slags feministisk kamp, som giver os RAWA. Og denne middelklasse, repræsentanten for menneskerettigheder i hele verden, er, når alt kommer til alt, epistemologisk adskilt fra de nederste klasser i sin egen kultur.” (Spivak 2004: 89)
På trods af RAWA's strid med Feminist Majority Foundation er de dog fortsat medskyldige i fordrivelsen af andre afghanske kvindeorganisationer, der ikke har så nem adgang til den globale feministiske scene. Spivaks advarsel er en påmindelse om, at den dominerende reaktion på feministiske diskurser om muslimske kvinder er en ren symbolsk liberal undskyldning, som ofte lader den binære konstruktion vesten/islam stå ubestridt.

Idet USA positionerer sig selv som en exceptionel ekspert i antiterrorisme, læner den amerikanske exceptionalisme sig op ad andre landes exceptionalisme, især den tætte allierede i Mellemøsten, Israels. Den exceptionelle status, som Israels nationale sikkerhed har, og den langvarige "eksistentielle" trussel imod landet, fordi det er "indblandet i en konflikt af hidtil usete dimensioner", forløber således: "Exceptionel sårbarhed" fører til "exceptionelle sikkerhedsbehov", og den risiko, som er forbundet med dette, lettes og besejres angiveligt af "exceptionelle antiterrorismeteknologier" (Merom 1999: 414, 413). I dette aftalte spil mellem amerikanske og israelske statsinteresser, som defineres ud fra en fælles afstandtagen til muslimer, væves narrativer om offerroller sammen med krav om exceptionalisme, frem for at de punkterer, modsiger eller ophæver sådanne krav. Med andre ord er den israelske nationalstat fortsat involveret i en cyklus af, hvad der opfattes som exceptionelle trusler om vold, hvilket kræver en exceptionel magtanvendelse mod den palæstinensiske befolkning, hvilket nu gentages af repræsentanter fra den amerikanske regering i deres officielle udtalelser om mulige terrorrisici for at overbevise de amerikanske borgere om at støtte krigen mod terror.

Amy Kaplan reflekterer over nuværende debatter om USA som et imperium og bemærker:

Ideen om imperiet har paradoksalt nok altid indebåret en fornemmelse af grænser i tid og 
sted, en narrativ om at rejse sig og om at falde, hvilket den amerikanske exceptionalisme længe har holdt nede (Kaplan 2004).

Senere påpeger hun, at

Benægtelsen og fornægtelsen af imperiet længe har været ideologiske grundsten i amerikansk imperialisme og en afgørende bestanddel af amerikansk exceptionalisme (Kaplan 2004: 3).

For Kaplan er resultatet af adskillelsen af exceptionalismen fra imperiet todelt og til dels selvmodsigende: Det overlegne USA er ikke underlagt imperiets mangler, da imperiets struktur er ustabil, og da imperiet uundgåeligt vil falde; og USA giver det indtryk, at imperiet står udenfor landets egen hæderlige moralske opførsel, således at al statsvold moralsk, kulturelt eller politisk ses som alt andet end imperiets vold. Amerikansk exceptionalisme hænger sammen med et transcendensnarrativ, der placerer USA over imperiet i disse to parametre, et projekt som hjælpes på vej af, hvad Domenico Losurdo kalder:

den fundamentale tendens til at transformere judeo-kristne traditioner til en slags national religion, der berettiger det amerikanske folks exceptionalisme og den hellige mission, som de er betroet med ('Manifest Destiny').

(Losurdo 2004: 365)

Kaplan bemærker, at nuværende imperienarrativer "tager amerikansk exceptionalisme til nye højder" og at et samtidigt "paradoksalt krav om unikhed og universalitet" er sidestillet, da "det deler et teleologisk narrativ om uundgåelighed", hvilket placerer USA som dommer over passende etik, menneskerettigheder og demokratisk opførsel, samtidig med at det uden tøven fritager sig selv fra sådanne universaliserende mandater (Kaplan 2004: 5-6. Kaplan citerer Hassner 2002).

Uanset om man er enig i, at amerikansk exceptionalisme har opnået "nye højder" eller ej, så illustrerer Kaplans analyse fuldkomment det uløselige forhold mellem undtagelsestilstandsdiskurser og exceptionalisme. At gøre krav på unikhed (undtagelse $=$ særegenhed) og universalitet (exceptionel = at lade et teleologisk narrativ gå i arv) er ikke helt så paradoksalt, som Kaplan insisterer på, for undtagelsestilstanden anses som nødvendig for at kunne genoprette, beskytte og vedligeholde status quo; den normative orden, som giver USA mulighed for at hylde sin påståede universalitet. USA's uundværlighed er således vævet sammen med det naturaliserede bindeled mellem særegenhed og telos, hvorved paradokset visner væk. ${ }^{9}$ Undtagelsestilstandsdiskurser rationaliserer ekstrem vold under dække af at ville beskytte en form for livsstil og dem, som er privilegerede nok til at leve den. Giorgio Agamben bemærker, at biopolitik fortsat søger at redefinere grænserne mellem liv og død:

Undtagelsestilstanden er hverken ekstern eller intern i forhold til den juridiske orden, og problemet med at definere den handler netop om en tærskel eller en ligegyldighedszone, hvor indenfor og udenfor ikke ekskluderer hinanden, men nærmere blander sig med hinanden. (Agamben 2005: 23)

Undtagelsens temporalitet forsøger at skjule sig selv; den hektiske nødtilstand er et alibi for den stille vished om den liberale og demokratiske regerings langsomme arbejdsparadigme, et alibi, der er nødvendigt for at fornægte $\sin$ forbindelse til totalitære regeringer. Undtagelsestilstanden fungerer således, at staten i forsøget på at udvide sit territorium, sin tilstedeværelse og $\sin$ magt gemmer eller fornægter sin eksistens og kun dukker op til overfladen kortvarigt og med nok ressourcer til at legitimere besættelsen af yderligere terræn. Agamben sammenligner undtagelsestilstandens udvendige indvendige område med et Möbiusbånd: Det øjeblik, noget er på ydersiden, er det 
samtidig allerede på indersiden (Agamben 1998: 37). Narr det kommer til undtagelsestilstanden, bliver undtagelsen ubemærket til reglen, og det exceptionelle normaliseres som et regulerende ideal eller en ramme; det exceptionelle er den overlegenhed, der overskrider parametrene for at være et korrekt subjekt, hvilket samtidig redefinerer disse parametre for at normativisere og usynliggøre (men samtidig gennemskueliggøre) sin egen overlegenhed eller singularitet.

Seksuel exceptionalisme fungerer også ved at tilsløre sin egen overvågning af grænserne for acceptable køns-, race- og klasseformationer. Det vil sige, at homoseksuel seksuel exceptionalisme ikke nødvendigvis modsiger eller underminerer heteroseksuel seksuel exceptionalisme; faktisk kan den støtte den heteronormativitet og de klasse-, race- og borgerskabsprivilegier, som følger med den. Den historiske og samtidige produktion af en spirende normativitet, nemlig homonormativiteten, forbinder anerkendelsen af homoseksuelle subjekter, både lovmæssigt og i form af repræsentation, med den amerikanske imperialismes nationale og transnationale politiske dagsorden. Homonormativitet kan læses som en formation, der er medskyldig til og inviteret ind $i$ den biopolitiske valorisering af liv i form af sin beboelse og reproduktion af heteronormative normer. En af den seksuelle exceptionalismes primære mekanismer er mobiliseret af diskurser om seksuel undertrykkelse - en nutidig version af Foucaults repressionshypotese - som skaber bio- og geopolitiske globale kortlægninger af seksuelle, kulturelle normer. At optrævle diskurser om amerikansk seksuel exceptionalisme er vitalt for at kritisere amerikanske imperiumpraksisser (hvoraf de fleste kun af og til tager spørgsmål om køn og seksualitet op) og for udvidelsen af queer-identiteter til ikke længere kun at dække snævre konceptualiserede rammer for seksuel identitet og seksuelle handlinger.

Eftersom det nuværende politiske klima omkring amerikansk nationalisme er så afhængigt af en homofobisk dæmonisering af seksuelle andre, kan argumentet om, at homoseksualitet er inkluderet i og bidrager positivt til optimeringen af liv, muligvis virke ulogisk. Det er dog alligevel af afgørende betydning, at vi fortsætter med at læse de raciale, kønsmæssige, klassemæssige og nationale dimensioner af disse nedgørende mekanismer. Sa jeg fortsætter med to forbehold. For det første: At hævde at nogle eller visse homoseksuelle kroppe indikerer homonormativ nationalisme - homonationalisme - er på ingen måde ment som en nægtelse, reducering eller afvisning af den daglige voldelige diskriminering, fysiske eller seksuelle overgreb, udstødelse fra familien, økonomiske ulemper og mangel på social og juridisk berettigelse, som seksuelle andre jævnligt udsættes for; kort sagt, de fleste queers, hvad enten som subjekter eller befolkninger, befinder sig stadig i deciderede eller potentielle døds-regimer. I denne tekst arbejder jeg mig igennem de mangfoldige spor af racialisering og af-nationalisering af seksuelle andre, der skaber rammerne for den voldelige nedgradering til døden. Spektret af modstand mod homoægteskaber, adoptionsog forældrerettigheder for homoseksuelle, “Don't Ask, Don't Tell"-politik og privatiseringen af seksualitet indikerer, at beskyttelsen af liv, som opnås i kraft af nationalt tilhørsforhold, i bedste fald er en skrøbelig invitation. For det andet: Der er ingen organisk enhed eller samhørighed mellem homonationalismer; de er delvise, fragmenterede, ujævne formationer, som er implementeret i det momentum, der pendulerer mellem inklusion og eksklusion, hvoraf nogle forsvinder lige så hurtigt, som de opstår. Omkostningerne, der er forbundet med at blive foldet ind i livet, kan derfor være ret høje, både for subjekter, som interpelleres af eller stræber efter den tætte inklusivitet, som homonormativiteten tilbyder i dette øjeblik, ligesom for dem, der nægtes adgang på grund af deres uønskede race, etnicitet, religion, klasse, nationale herkomst, alder eller kropslig duelighed. Som Barry D. 
Adams påpeger, kan det også være, at USA kun er exceptionelt i den grad at det globalt set er $u$ exceptionelt, en vinkel som understreger det tilfældige og uforudsigelige ved enhver imødekommenhed mod queer liv. Adams pointerer ironisk, at når det kommer til juridisk anerkendelse af homoseksuelle forhold, halter USA til en vis grad bagefter de fleste europæiske lande såvel som Canada, Brasilien, Colombia, New Zealand, Australien og Sydafrika - en tilbageståenhed som USA ofte tilskriver andre lande i sammenligning med sig selv (Adam 2003). Vi kan også sige, at USA er investeret $\mathrm{i}$ at være exceptionelt heteronormativ, selvom det hævder at være exceptionelt tolerant overfor (homoseksuel) forskellighed. Men da Adams' argument baseres på ideen om at være efter, skriver det sig ind $i$ en foruroligende modernitetsteleologi, som, til trods for at det situerer exceptionalisme som et narrativ, der maskerer eller tilslører regionale forskelle, tvinger ligesindede lande ind på en ensidig rute frem for en bevægelse i flere retninger. Spørgsmålet om, hvorvidt USA faktisk er exceptionel, har domineret forskellige debatter inden for blandt andet historie, amerikanske studier og statskundskab, men fokus har været på komparative empiriske studier, der ikke gør meget for at udfordre eller sætte spørgsmålstegn ved denne telos. ${ }^{10}$ Med omfanget af diskussionen om amerikansk exceptionalisme taget i betragtning er det ikke min ambition at afgøre, hvorvidt USA faktisk er exceptionel - exceptionelt god eller fremmelig, eller exceptionelt bagud eller anderledes - men derimod at illustrere, hvordan krav på exceptionalisme er fyldt med uudforskede diskurser om race, seksualitet, køn og klasse. Desuden afhænger exceptionalisme af udsletningen af netop disse modaliteter for at kunne fungere; det er netop med disse udelukkelser, at undtagelsen, som er nødvendig for beskyttelsen af livets egenskaber, bliver til normen, og at det exceptionelle, og de subjekter, som udfører denne opgave, bliver normalen.

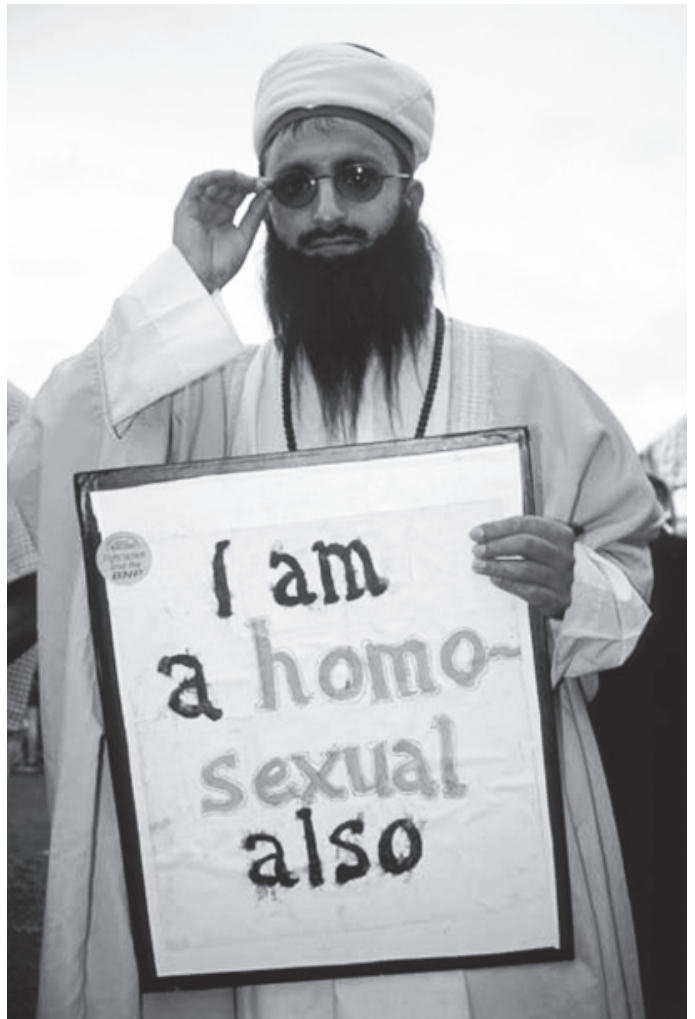

Figur 1: Poulomi Desai, I Am a Homosexual Also. Fra Poulomi Desai og Parminder Sekhon, Red Threads: The South Asian Queer Connection in Photographs. London: Diva Books, 2003. Genoptrykt med kunstnerens tilladelse.

\section{QUEER SOM REGULERENDE}

Amerikansk seksuel exceptionalisme har europæiske modstykker, især i Storbritannien og Holland, som udvider, krydser, er i kontrast til og ofte styrker amerikanske homonormative formationer. Det er afgørende at have ekkoerne og afvigelserne mellem landene for øje på grund af de forskellige kolonihistorier, de forskellige migrationsruter og klasseforskelle mellem amerikanske muslimer og europæiske muslimer. ${ }^{11} \mathrm{Hvad}$ betyder og antyder erklæringen i Figur 1: "Jeg er også homoseksuel"? 
Hvilken slags repræsentativ valuta, kulturel kapital og affektiv resonans skaber og afliver denne erklæring i vores nuværende politiske landskab? På dette utrolige foto af Poulomi Desai, fra en samling af brittisk sydasiatisk queer fotografi fra 2003, ser vi en muslimsk gejstlig, der fremviser terrorist-drag (Desai og Sekhon 2003). Dette provokerende billede af en figur i Osama bin Laden-drag placerer os på ny i en forstyrrende queer epistemologi og ontologi. Jeg bruger "drag” som en foreløbig term: Til trods for make-up'en, klædedragten, det falske skæg og konteksterne (både Storbritanniens politiske landskab og bogens queer dokumentariske vinkel) kan termen gentage den normative opfattelse af en radikal usammenlignelighed mellem de to subjektpositioner og implementere en normativ modernistisk binær ramme frem for en meget mere kompleks trekant bestående af sex-gender-begær. Den muslimske religiøse klædedragt bliver både naturaliseret som Osama bin Ladens fundamentalistiske dragt og genvundet som en skueplads for queer begær og for subjekter med et queer begær, hvilket forstyrrer både konventionelle epistemologiske og ontologiske fremførelser af denne krop.

Billedet er, for at sige det mildt, overraskende for den queer liberale billedverden, der er på spil i nutidige diskurser om terrorisme og antiterrorisme: Afgørende sekulært, nådesløs i sin forståelse af (irrationel, ulogisk, meningsløs) religion, tro eller spiritualitet forstået som undergangen for enhver rationel politik. Queer sekularisme kræver en specifik transgression af normer, religiøse normer, der ellers opfattes som det, der binder subjektet til en særligt ekstrem religiøs ramme. Det queer, aktive subjekt vil altid kun ses som værende udenfor religionens normgivende restriktioner, en sammensmeltning af agens og modstand.

Til muslimer og queer subjekter, som afviser queer religiøse skikke, kommunikerer skiltet: Jeg er også dig, og jeg er indeni dig. Queer arabere og muslimer, der er dobbelt anklaget dels af den fundamentalistiske religion, som de praktiserer eller flygter fra og dels den terroristkrop, som denne religion producerer, er enten befriet (og USA og Europa er ofte konteksten for denne befrielse) eller har kun adgang til en irrationel, patologisk seksualitet eller queerhed. Disse sammenfiltringer, som muligvis til en vis grad kan undgås af judeo-kristne queers, plager muslimske queers på grund af den udbredte sammenblanding af muslimsk med islamisk og arabisk: muslim $=$ islam $=$ araber. Religion og i særdeleshed islam har nu afløst race som den ene side af den uforenelige binære opposition mellem queer og noget andet. For queer arabere og muslimer forstærkes enten/eller-situationen: Queer sekularisme forstår overholdelse af religiøs overbevisning, deltagelse i religiøse offentlige ritualer, hengivenhed til trosbaserede eller spirituelle praksisser og bopæl i en islamisk nationalstat (hvilket læner sig op af en formodning om adskillelse af kirke og stat i ikke-islamiske nationalstater; for eksempel benægtelsen af kristen fundamentalisme som statspraksis i USA) som markører for underkuet og undertrykt seksualitet uden agens. Uanset deres komplekse tilhørsforhold til islam, arabiske nationalstater og muslimsk identitet, evalueres alle queer muslimers agens altid igennem den queer liberale sekularismes regulerende system. ${ }^{12}$ Dette bidrager yderligere til apolitiske læsninger, som typisk tilskrives afvisningen af vestlig modernitet, som kan blive udført af islamiske følgere. Queer sekularisme viser sig på mest ondartet vis i relation til islam, fordi islam i hele sin spændvidde ofte beskrives som urokkelig og mindre modtagelig overfor homoseksualitet end kristendom og jødedom, til trods for nogle queer muslimers indvendinger, der “insisterer på at deres religiøse og familiemæssige kampe ikke er meget anderledes end de er det for kristne og jødiske queers." 13 På samme måde som i spørgsmålet om exceptionalisme er jeg ikke interesseret $i$ at bestemme, hvorvidt disse påstande er sande eller falske, jeg vil derimod undersøge denne 
diskurs' modstandskraft og jerngreb, dens opererende logik og de myter og realiteter, som den producerer.

Hvorfor lige "homoseksuel", klinisk som resonerer med medikaliseringen af homoseksualitet i Vesten og antyder en i antropologisk forstand umoden version af queerhed ligesom inden for diskurser om universelle rettigheder? De sekulære homoseksuelle menneskerettigheders rammesætning af islamisk seksuel undertrykkelse forveksler statsundertrykkelse med seksuel undertrykkelse, hvilket i bund og grund forhindrer en produktiv effekt af de juridiske strukturer (endnu en gengivelse af den repressionshypotese, som Foucault advarer imod). Denne nutidige version af repression står ikke i modsætning til koloniale fantasier om orientalistisk seksuel umådeholdenhed, perversitet og pædofili. I samme bevægelse umuliggøres eksistensen for det moderne homoseksuelle subjekt, mens terroristen til evig tid er queer, upassende seksuel, indlejret $\mathrm{i}$ en "altid allerede homoseksualiseret befolkning” (Massad 2002: 363). I denne gengivelse er mandlig homosocialitet forbundet med pædofili, tilskrevet den tilsyneladende mangel på seksuel kontakt med kvinder, eller konstant fejllæst som homoseksualitet. Omvendt antages kvindelig homosocialitet, som er gemt væk, at signalere køns- og seksualitetsundertrykkelse. ${ }^{14}$ Fordringen om homoseksualitet imødegår to tendenser: Den dagligdags implementering af islamisk seksuel undertrykkelse, som plager menneskerettigheds-, liberale queer og feministiske diskurser, og den orientalistiske våde drøm om en lystfuld overflod af pædofili, sodomi og pervers seksualitet. I intersektionen mellem krop og befolkning udfordrer Desais billede den perverse patologiske seksualisering af terrorist-lookalike befolkninger, ved at gøre krav på en modernistisk subjekt-identitet - via religion, ikke til trods for religion - som typisk er reserveret til homonormative (hvide, vestlige eller vestligficerede) kroppe. Mens kravet om modernistisk seksuel subjektstatus udøves - en subjektstatus, som ofte tilskrives globaliseringens homogeniserende kræfter - udfordrer den urovækkende, monstrøse terroristkropslighed, som bebor denne seksuelle subjektstatus, de selvsamme termer, som den reguleres ud fra.

Visuelt genvinder kroppen bøsseidentiteten, kvindagtigheden og den forfejlede maskulinitet, som altid allerede er en del af navngivningen af terroristen, og iscenesætter yderligere modstand overfor de nemme gentagelser af beskyldninger om at være terrorist. De (hvide) sekulære normer, som queerhed retter sig efter, bidrager i høj grad til (racistiske) islamofobiske og homofobiske repræsentationer af terrorister. Det vil sige, at det queer overskridende subjekt opnår sin legitimitet og valuta på dette historiske tidspunkt takket være en manglende evne til at udrede disse repræsentationer via en bredere formulering af queer religiøsitet. Queer sekularisme konstituerer og er konstitueret af det queer autonome liberale subjekt i modsætning til og igennem konkretiseringen af netop de patologiske, irrationelle seksualiteter, som er specifikke for diskurser om den skyldige terrorist.

Ordet "også” i "Jeg er også homoseksuel" fungerer som en slags insisterende "det må I bare leve med" og signalerer forholdene for muslimske og queer identiteter til et bredt publikum, hvilket udfordrer de gensidigt ekskluderende orientalistiske versioner af muslim og homoseksuel. Den muslimske/ homoseksuelle binaritets singularitet er blevet forstærket i USA og globalt siden 11 . september 2001. Grupper som den amerikanske LGBTIQ Al-Fatiha Foundation (fra den første linje af Koranen, som betyder "Begyndelsen") er blevet undersøgt som interessante afarter, som en queer anomali. ${ }^{15}$ Den queer muslimske filmskaber Parvez Sharma arbejder på en dokumentar ved navn In the Name of Allah, der understreger et særligt karakteristisk eksempel på denne tendens ved at pege på den følgende beskrivelse af sit arbejde og sin aktivisme: 
Efter 11. september var [Sharma's arbejde] svært for mange amerikanske kommentatorer at forestille sig: Muslimsk, seksuel diversitet, fællesskab, stemme og rettigheder (Sharma 2004). ${ }^{16}$

Mubarak Dahir rapporterer om queer muslimske liv efter angrebene:

'Det er slemt nok at være hadet for at være homoseksuel', siger Mahmoud, en muslim, som bor i Pittsburgh, og som har bedt om ikke at få sit rigtige navn nævnt. 'Men nu er jeg også hadet for at være muslim. Og den mistro lader til at komme fra alle amerikanere. Jeg havde håbet, at mine homoseksuelle venner, som jo selv er ofre for så mange fordomme, ville være mere tilbøjelige til at være kritiske overfor stereotyperne. Men mine homoseksuelle venner er ikke bedre end alle de andre.' (Dahir 2002)

Længere nede i artiklen siger Mahmoud, "Siden 11. september har jeg været mere afhængig af mit religiøse fællesskab for at få styrke." (Dahir 2002: 91) Ifti Nazim fra SANGAT/Chicago (en organisation og støttegruppe for bøsser, lesbiske, biseksuelle og transpersoner fra Indien, Pakistan, Bangladesh, Sri Lanka, Nepal, Afghanistan, Iran, Myanmar og resten af de sydasiatiske lande) er enig og siger, at mange heteroseksuelle muslimer i Chicago blev mere positivt stemte overfor ham som representant for deres fællesskab.

"Mange konservative muslimske ledere rækker nu ud til mainstream bøsseorganisationer... Jeg er meget glad, men også chokeret, for jeg havde aldrig forestillet mig, at det kunne være sådan her. Det er alt sammen på grund af 11. September". (Smith 2002)

Disse kommentarer er ikke mindst betydningsfulde, fordi queer sekularisme, og queer overskridende subjekt-status generelt, også ligger under for den stærke overbevisning, at raciale fællesskaber er mere homofobiske end hvide mainstream queer fællesskaber er racistiske. De, der er fanget i mellemrummene, ikke-hvide queer subjekter, formodes langt nemmere at indgå i dialog med hvide mainstream queer personer, i politik, sociale arenaer, erotiske forbindelser og arrangementer end de gør med deres religiøse eller raciale fællesskaber, familier, kirker, ritualer, fejringer, bryllupper (hvor den liberale springe-ud-telos fungerer som et accept-barometer). Herved gøres kritik af homofobi inden for ens eget fællesskab implicit vigtigere og mere presserende end kritik af racisme indenfor mainstream queer fællesskaber. (En fortolkning af klistermærket med teksten "Fight Racism and the [British National Party]" er, at det fungerer som en eksplicit udfordring af de implicitte hvidheds- og statsborgerskabs- privilegier indenfor queer liberalisme).

Et nøgleeksempel, der demonstrerer denne pointe, er debatten om beslutningen om at afholde World Pride 2006 i Jerusalem. En queer gruppe fra New York, "No Pride without Palestinians", kæmpede for at flytte World Pride til et andet sted med argumentet, at palæstinensiske queers (og mange arabere fra nabolandene) ville blive forment adgang til festlighederne, og at de, som allerede var til stede, ville risikere endnu mere overvågning, regulering, chikane og deportation. Gruppen argumenterede for at "flytte World Pride til et sted, hvor alle queer personer kan fejre reel frihed" og bemærkede, at den israelske stat ved mange lejligheder har deporteret "queer menneskerettighedsforkæmpere, som kæmper for at stoppe besættelsen af Palæstina." På hjemmesiden stod der:

World Pride er en fejring af queer frihed. At holde World Pride i Jerusalem - en besat by, en fest arrangeret af en voldelig besættelsesmagt - er et slag i ansigtet på friheden.... Det er ikke 'World Pride' uden palæstinensiske og arabiske queers, og vi nægter at lade vores queer festligheder konkurrere med palæstinensernes frihed (No Pride in Occupation u.d.). 
Organisationen som koordinerer World Pride, InterPride, har base i USA og er primært drevet af amerikanere og nogle europæere. Israels beslutning om at være vært for World Pride var irriterende strategisk, da arrangementet ville få Israel til at fremstå som et tolerant, forskelligartet og demokratisk samfund, og fjerne opmærksomheden fra landets dystre menneskerettighedsforhold yderligere. (Volden og spændingerne mellem ultraortodokse, andre konservative jødiske sekter og queer jøder, som typisk er udvisket, blev understreget under Gay Pride paraden i 2005, hvor tre deltagere blev stukket ned af "en mand i ultraortodoks påklædning" (Sheffer and Weiss 2005)). Fra kredsløbet af "transnational queerhed", førte denne beslutning til hemmelige aftaler med det undertrykkende israelske statspoliti imod palæstinenserne samtidig med, at staten også opmuntrede og autoriserede åbenlyse anti-palæstinensiske synspunkter (Bacchetta 2002). Beslutningen fastholder også, at israelske queers kan opnå legitimering fra den israelske stat såvel som via transnational queerhed $\mathrm{i}$ kampen for og med ret til suverænitet, mens palæstinensiske queers læses teleologisk gennem en fanatisk linse af islamisk fundamentalisme, fremfor gennem den palæstinensiske kamp for selvbestemmelse og anerkendelse som stat, gennem interessen i progressiv queer politik, eller gennem en liberal humanistisk fortolkning af begær. ${ }^{17}$ Det er yderst vigtigt, at queer jødiske og queer palæstinensiske aktivister blandt andre lobbyede sammen for at ændre værtslandet for World Pride 2006.18 Det er også af afgørende betydning, at disse fælles indsatser afviser queer missionerende, frigørende eller transcendente paradigmer, som kan placere palæstinensiske queers $i$ et offernarrativ parallelt til det, som dyrkes af den israelske stat, de kæmper imod.

Endnu en fælde finder man i valoriseringen af ofre som fortrop i kampen ved at fremhæve dem som helte. Aktivisterne i den britisk-baserede queer gruppe OutRage! ba-

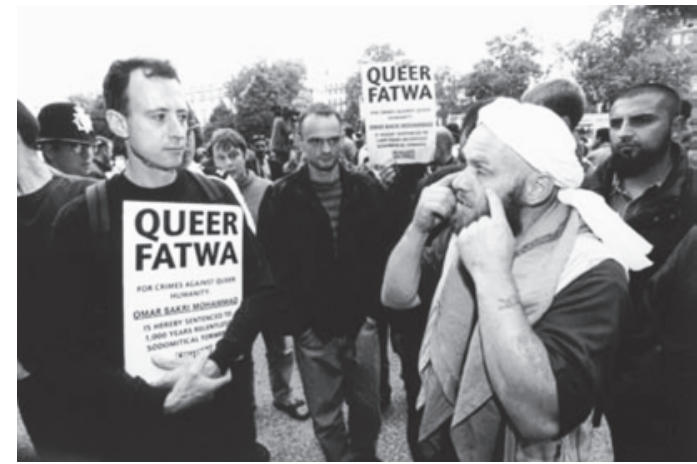

Figur 2: Outrage! grundlegger Peter Tatchell med "Queer Fatwa" skilt. Foto af Piers Allardyce (for Outrage!). Genoptrykt med kunstnerens tilladelse.

lancerer faretruende på denne smalle line. OutRage! krævede en "queer fatwa" (en temmelig tåbelig appropriering af begrebet "fatwa") mod Storbritanniens "islamiske fundamentalistiske" leder Omar Bakri Mohammed ved en demonstration på Kvindernes internationale kampdag i London (8. marts 2005) med plakater, som proklamerede "Solidaritet med islamiske kvinder" og "Ingen Islamisk stat eller Shar'ia lov".19 Den sidstnævnte overbevisning afspejler queer sekularisme; det er utænkeligt, at kvinder eller queers kunne forhandle eller have agens inden for en islamisk stat. Ved Befri Palæstina-demonstrationen i London den 21. maj 2005 bar OutRage! skilte med teksten: "Israel: Stop forfølgelsen af Palæstina! Palæstina: Stop forfølgelsen af queers!” og “Stop æresdrab på kvinder og bøsser i Palæstina.” Disse tilsyneladende harmløse og politisk korrekte beskeder, som stammer fra gruppens engagement $\mathrm{i}$ at protestere mod "islamofobi og homofobi”, bekræfter desværre Israel og jødedommens modernitet og Palæstina og islams uhyrlighed. At afgrænse queer undertrykkelse til at finde sted i Palæstina - en undertrykkelse som sidestilles Israels besættelse af Palæstina - fjerner fokus fra Israels 
forfølgelse af queer palæstinensere. Israels egen forfølgelse af queer israelere - for Israel er ikke just fritaget for homofobisk vold mod sine egne borgere uanset religiøs eller etnisk baggrund - slettes i denne trickle-down sloganmodel. Denne dialektiske analogi, hvori Israels forfølgelse af palæstinensere er "ligesom" Palæstinas forfølgelse af queers, er en stor bjørnetjeneste for de usammenligneligt vanskelige situationer, der er på spil, og den nægter nogen yderlige sammenhæng mellem de to, den nægter endda, at den ene form for undertrykkelse kan vedholde eller endda muliggøre eksistensen af den anden. Desuden peger denne analogi på vitale forbindelser: Mellem de disciplinære frihedsparadigmer for homoseksuelle menneskerettigheder og den eskalerende islamiske statsundertrykkelse af ikke-normative seksualiteter, mellem hærdningen af binære kønsoppositioner i moderniteten og dens indførelse i forskelligt kønnede samfund (Massad 2002; Fanon 1967). og mellem historierne om kolonialismen og neokolonialismens økonomiske og kulturelle dominans og de koloniserede befolkningers evige navigation inden for disse magtnetværk. Ironisk nok er den selvsamme logik, som danner baggrund for den israelske stats rationalisering og retfærdiggørelse af sin besættelse af Palæstina og den frygtelige behandling af palæstinenserne - den angivelige barbarisme og inhumanitet hos primitive, fundamen-talistiske muslimsk-palæstinensiske selvmords-bomber-terrorister - genindskrevet i OutRage!'s beskeder ved Befri Palæstina-demonstrationen. Den forskellige behandling af queers $i$ disse transnationale kontekster er voldsomt afhængig af nationale og raciale tilhørsforhold og retten til eller fornægtelsen af statsborgerskab.

OutRage! er blevet beskyldt for at bruge en queer platform til at udbrede anti-muslimsk retorik, hvilket ikke er en ubegrundet frygt beviserne taget $i$ betragtning. ${ }^{20}$ Outrage!'s mest prominente aktivist, Peter Tatchell, advarede i 1995 mod islamisk fundamentalisme og sagde, at dets indtog "har indledt en æra med religiøs obskurantisme og intolerans," hvilket han refererede til som "Den nye mørke middelalder".21 Som et eksempel på paranoiaen såvel som den allestedsnærværende polarisering af muslimske og homoseksuelle subjekter skrev han i 1998:

De politiske konsekvenser for det homoseksuelle miljø kan være alvorlige. I takt med at fundamentalisterne får følgere, kan homofobiske muslimske vælgere måske få indflydelse på valgresultatet i 20 eller flere mindre valgkredse (Thatchell 1998).22

Som respons på OutRage!'s protest mod den "islamiske fundamentalist" Yusuf alQaradawis besøg i Storbritannien i sommeren 2004 skrev Londons borgmester Ken Livingstone, at "en bølge af islamofobi" har overskygget formålet med al-Qaradawis besøg: En konference om kvinders ret til at vælge at bære det muslimske tørklæde (motiveret af forbuddet mod tørklæder i de franske skoler). Et andet brev, underskrevet af the National Assembly against Racism, the National Union of Students Black LGB, the Lesbian and Gay Coalition against Racism og Operation Black Vote, udtrykker lignende følelser ("Vi må udtrykke vores bekymring over indholdet og tonen i OutRage!'s og andres kampagner i forbindelse med Yusuf al-Qaradawi, som vi mener, er en del af den stigende tendens til anti-muslimsk hysteri”) og peger på “en magtfuld og farlig kampagne for at fremstille muslimsk fundamentalisme som den mest seriøse trussel mod verden", en kampagne som udspringer fra Vesteuropa og USA (Livingstone et al. 2004). OutRage!'s del i dette er en anklage mod Dr. al-Qaradawis hjemmeside, Islamonline, for at støtte afbrænding og stening af homoseksuelle samt vold mod kvinder (OutRage! 2004).

Min hensigt er ikke at dykke ned i OutRage!'s indviklede historie som politisk organisation. Det er heller ikke at kritisere 
organisationens mangesidede arbejde: alliancen med the Black Gay Men's Advisory Group, the Queer Youth Alliance og the Green Party, demonstrationer mod forbuddet mod xgteskaber mellem personer af samme køn, Vatikanet og den katolske kirke, mod de homofobiske tekster skrevet af de caribiske musikere Beenie Man, Vybz Kartel, Bounty Killer, Elephant Man og Buju Banton, mod tortur og henrettelse af homoseksuelle mænd i Saudi Arabien, mod deportationen af de homoseksuelle asylans $\varnothing-$ gere Ramzi Isalam fra Algeriet og Vadim Selyava fra Hviderusland og mod Mugabes diktatur i Zimbabwe, samt ceremonierne for de dræbte homoseksuelle aktivister Brian Williamson fra Jamaica og Fannyann Eddy fra Sierra Leone - og listen kunne sikkert fortsætte (OutRage! 2005a) Jeg vil hellere fokusere på, hvordan Befri Palæstinademonstrationen fungerer som et eksempel på en fremstilling af solidaritet med andre queers, ofte i form af velmente inklusionshandlinger og anerkendelse af multikulturel diversitet, som uforvarende kan komme til at gentage de selvsamme neokoloniale antagelser, som OutRage! søger at fjerne.

Men der er noget endnu mere subtilt på spil her. Det binære par muslim/homoseksuel forvandler sig fra et narrativ om usammenlignelige subjektpositioner til en slags islam versus homoseksualitet-befolkningstovtrækning: En forvandling, som kan afsløre de dobbelte strømninger af konservative homonormative ideologier og queer liberalisme. Et eksempel på dette var den hollandske politiker, Pim Fortuyn, som ville sætte en stopper for immigration og asyl og som brugte anti-muslimsk retorik til at sikre sit parti, Lijst Pim Fortuyn, 26 mandater i parlamentet; han blev myrdet af en dyrerettighedsaktivist 9 dage før valgsejren (BBC News 2002; New York Times 2002). Yoshi Furuhashi skriver:

Pim Fortuyns succes (...) signalerer en ny æra for hvid homoseksuel mandlig politik. Ved ihærdigt at promovere en anti-indvandrings-

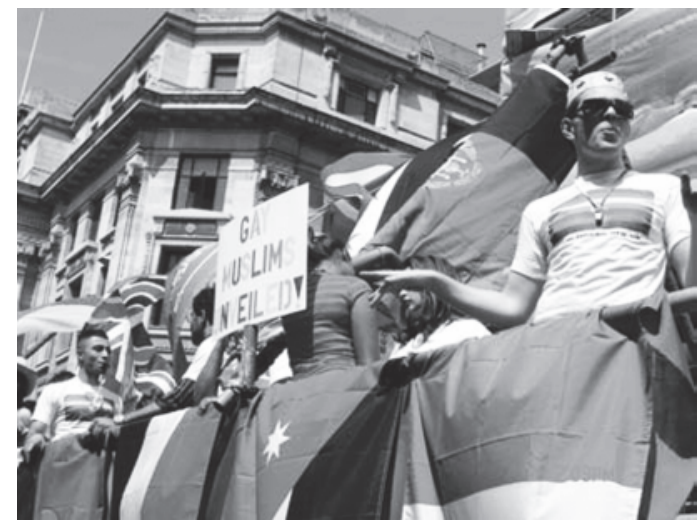

Figur 3: Imam-pogn til EuroPride 2006, London. Foto af Liz Van Gerven. Genoptrykt med kunstnerens tilladelse.

politik og markedsføre den demagogisk med anti-muslimske fordomme viste Fortuyn, at højrefløjspopulisme meget vel kan være homoseksuelt og enormt populært at sætte i gang (Furuhashi 2004).

Til forskel fra hvide, homoseksuelle, mandlige politikere på højrefløjen, som “arbejder imod egne interesser" og som er blevet udstødt og forvist af andre højreorienterede politikere, peger Furuhashi på, at spørgsmålet om retten til ægteskab vil give disse homoseksuelle politikere endnu mere troværdighed og legitimitet (Furuhashi 2004). Sandip Roy pointerer, at efter bombeangrebene i London den 7. juli 2005, hvor gerningsmændene ikke var terrorister fra et fjernt land, som havde infiltreret det hellige hjemland, men derimod hjemmedyrkede britiske muslimer, blev Europa symbolsk opdelt i én arena, hvor legaliseringen af $æ g$ teskaber mellem personer af samme køn er en prioritet (Holland, Belgien, Spanien og Storbritannien), og en anden arena, hvor islamisk fundamentalisme angiveligt regerer og for eksempel er ansvarlig for filmskaberen Theo van Goghs død.

Homoxgteskaber, der handler "mindre om rettigheder for homoseksuelle og mere 
om at kodificere et ideal om europæiske værdier" (Roy 2005), er blevet en høj, men nødvendig forsikringspræmie i Europa, hvorved en ellers ambivalent og måske endda fjendtlig befolkning kan garantere den ekstra følelse af sikkerhed, som købes til ved endnu en markør af distancen mellem barbarisme og civilisation; en som retfærdiggør yderligere forfølgelse af en pervers seksualiseret og racialiseret muslimsk befolkning (pædofil, seksuel umådeholden og i seksuel overflod, men samtidig perverst undertrykt), som nægter at lade sig assimilere ordentligt i modsætning til de hæderlige homoseksuelle, som tager del i sanktionerede slægtskabsnormer. Homo-ægteskabsreformer katalogiserer således den raciale- og civilisationsmæssige kløft mellem europæere og muslimer samtidig med, at de udvisker de politiskøkonomiske kredsløb (klasse, indvandring), som understøtter sådanne oppositioner. Selvom konflikten i stigende grad præsenteres som en mellem queers og muslimer, er det, der er på spil i virkeligheden opretholdelsen af strenge grænser for kønsforskelle og de slægtskabsformer, som fastholder dem. ${ }^{23}$

Kort tid efter bombeangrebet hævdede OutRage! at have modtaget dødstrusler fra forskellige muslimske organisationer. ${ }^{24}$ Grupper som OutRage! signalerer for europæere, men også implicit for amerikanere, at muslimer udgør en serlig trussel mod homoseksuelle, at muslimske fundamentalister bevidst og specifikt gør homoseksuelle til mål, og at parametrene for denne opposition stemmer overens med parametrene for krigen mod terrorisme: civilisation versus barbarisme. Som eksemplerne med Fortuyn og OutRage! illustrerer, oplever vi i det globale nord en opblomstring af homonormativ islamofobi fra meget forskellige retninger, hvorved homonormative og queer mænd kan udleve forskellige former for nationalt, racialt og andre tilhørsforhold ved at bidrage til en fælles tilsvining af muslimer (Se Lunsing 2003).

For endnu engang at vende tilbage til vores foto af den muslimske fundamentalist/ perverse terrorist/homoseksuelle kan vi se, at denne svingning mellem et individualiseret subjektivitetsdilemma - er du muslim eller er du homoseksuel? - og en krig mellem gensidigt udelukkende befolkninger bekræfter den egentlige betydning af den uforenelige, stædige natur hos uassimilerede og uassimilerbare (arbejderklasse og europæiske) muslimer. Det disciplinerede homoseksuelle subjekt og den seksuelt patologiske terroristfigur er fortsat suspenderet sammen og i en accept af deres mulige sammenblanding benægtes et kollaps af den ene i den anden eller den enes rangering over den anden. Teksten modificerer billedet, dirigerer vores fortolkning af det, men kan ikke fuldstændig styre mængden af de orientalistiske troper, som er tilskrevet denne krop.

Nogle ville muligvis protestere ihærdigt mod forslaget om, at queer identiteter ligesom deres knap så "radikale" modstykker, homoseksuelle, bøsse- og lesbiske identiteter, også er impliceret i de mere og mere magtfulde hvide amerikanske nationalistiske formationer, da de foretrækker at se queerhed som overskridende identitetsnormer på helt unik vis. Det er dog netop ud fra dette fokus på transgression, at queerhed fortæller om sin egen exceptionalisme. Selvom man kunne pege på de åbenlyse problemer med visse (amerikanske, vestlige) feminismer og homobevægelsers emancipatoriske og missionerende tendenser, så har queerhed stadig sit eget exceptionelle begær: Exceptionalisme er en grundlæggende impuls, faktisk selve kernen af queerhed, som ellers hævder sig ved at være en anti-, trans- eller ikke-identitet. Paradigmet omkring homobefrielse og -frigørelse har produceret alle mulige former for narrativer: Om den overordnede homofobi i indvandrermiljøer og ikke-hvide miljøer, om strenge familieværdier og -skikke i disse miljøer, om en særlig nødvendig udvandring fra hjemmet, om komme-ud-teleologier. Vi har mindre forståelse for queer som et biopolitisk projekt, et der både løber parallelt med og krydser multikulturalisme, hvidhedens dominans, 
og som kunne konspirere med eller kollapse ind i befrielsesparadigmer. Mens liberale underbygninger fungerer som en konstant recentrering af normative homoseksuelle subjekter som eksklusivt befriende, så insisterer selvsamme tendenser på at recentrere det normative queer subjekt som et, der er eksklusivt overskridende.

Queerhed bliver her den modalitet, gennem hvilken "frihed fra normer" bliver til et regulerende queer ideal, som afgrænser den ideelle queer. Sara Ahmed hævder, at "mere refleksion over queer tilknytninger kan gøre det muligt for os, at undlade at fremføre assimilering og transgression som valgbare.” Hun påpeger yderligere:

Idealiseringen af bevægelse, eller bevægelsens transformation til en fetich, afhænger af eksklusionen af andre, som allerede er positionerede som ikke frie på samme måde (Ahmed 2005: 151-152).

Individuel frihed bliver til et valgbarometer i vurderingen og, i yderste forstand, reguleringen af queerhed.

Ahmeds post-marxistiske ramme fokuserer på materiel, kulturel og social kapital og ressourcer, som kunne begrænse "adgang" til queerhed, og foreslår, at queerhed kan være en elite-kosmopolitisk formulering betinget af forskellige mobilitetsregimer. Ironisk nok så kan "de som har adgang" til kulturel kapital og materielle ressourcer meget vel være de samme befolkninger, som mange ville beskylde for assimilering, da de udlever deres queerhed på den mest apolitiske eller konservative politiske måde. Den måde, jeg tænker på queerhed som exceptionelt, er forbundet med individualisme og det rationelle, liberale, humanistiske subjekt, det, Ahmed kalder "tilknytninger", og hvad jeg ville karakterisere som dybt psykiske investeringsregistre, som vi ofte ikke kan gøre rede for, og som nogle gange kan ses bedre af andre end af os selv. "Frihed fra normer" ræsonnerer med den liberale humanismes autorisering af det fuld- stændigt beherskede talende subjekt, der er utøjlet af hegemoni eller falsk bevidsthed, der muliggøres af kapitalismens tilbud om liv/stilisering, og som rationelt vælger moderne individualisme fremfor familiens besnærende bånd. Inden for denne problematiske definition af queerhed kan individuel agens kun læses som en modstand mod normer og ikke som et samspil med dem; således skabes der lighed mellem modstand og agens. Både Saba Mahmood og Ahmed kritiserer denne sammenblanding og retter opmærksomheden mod agens, som støtter og konsoliderer normer, men selv denne vending forudsætter nogle generelle, universelle forståelser for, hvad der tæller som norm, modstand og samspil. Som Mahmood spørger:

[Er det] muligt at identificere en universel kategori af handlinger - som for eksempel modstandshandlinger - udenfor de etiske og politiske tilstande, indenfor hvilke sådanne handlinger ellers får deres specifikke mening? (Mahmoud 2004: 9)

Frihedens retorik er selvfølgelig også et grundprincip i liberaldemokratiske filosofier og er bestemt et grundprincip i amerikansk exceptionalisme. Men queerhed som transgression (hvilket er trinnet over modstand, som nu er blevet en normativ handling) beror på en normativ forståelse af afvigelse, som altid er defineret i relation til normativitet, ofte universaliserende. Afvigelse hænger, trods påstande om frihed og individualitet, således ironisk nok sammen med regulerende regimer af queerhed - igennem, ikke på trods af, krav om transgression.

Mens Ahmed også ser queerhed som en udfordring af primært heteronormer, så inddrager queer teoretikere som Cathy Cohen queer politik i en intersektionel model, som ideelt set også skulle udfordre race- og klassenormer, når de møder heteronormer (Cohen 1997). Andre queer teoretikere ville definere queerhed som et poststrukturalistisk foretagende, der dekonstruerer ikke 
blot heteronormer, men selve logikken ved identitet i sig selv. I den første version af queerhed kan modstanden mod heteronormer være privilegeret på en måde, som udvisker effekten af denne modstand i forhold til mulig involvering med andre normer, såsom raciale, klasse-, køns- og statsborgerskabsprivilegier. Queer intersektionel analyse udfordrer denne regulerende queerhed, men kan i forsøget på dette risikere at undlade at underlægge egne rammer selvsamme kritik. I denne anden formulering er ikke-hvide queer- og queer indvandrermiljøer (for ikke at nævne kritik fra ikke-hvide queers) altid hævet over enhver kritik, en uholdbar position (de klassemæssige, religiøse, køns-queer, nationale, regionale, sproglige og generationsmæssige) spændinger taget i betragtning indenfor, iblandt og imellem miljøer med queers i eksil, indvandrere og ikke-hvide, hvorved nogle af deres egne konservative tilhørsforhold tilsløres. Omvendt sæetter det umulige standarder og forventninger til organisering og teoretisering af ikke-hvide queers, som altid er afhængige af modstands- transgressions- og subversionshandlinger og terræner. I det sidste tilfælde er alle (ens egne) identiteter (ikke kun kønlige og seksuelle) altid problematiske, hvilket fører til et umuligt transcenderende subjekt, som altid allerede er bevidst om magtens normativiserende kræfter og altid er klar og i stand til at nedbryde, modstå og overskride dem. Det er netop ved at nægte medskyldighed eller ved at gå ud fra, at man ikke er involveret i voldelige relationer med andre, og at man er placeret uden for dem, at volden holdes i live. Vold, især i liberal form, begås ofte nemmest på steder og i terræner, hvor muligheden for vold er utvetydigt fordømt.

Hvad er på spil, når man nedbryder de queer liberale binære par assimilation /transgression og sekularisme/religiøsitet? Hvis vi skal modstå modstanden, så bør læsninger af disse binære par med fokus på en bredere vifte af magtens tilknytning eller afstandtagen - som ofte er fyldt med mod- sætninger - ikke give ammunition til kritik, men rettere give plads til selvrefleksion, selvkritik og til at begå fejl. Det er nemt, men smertefuldt, at udpege de konservative elementer ved enhver politisk formation; det er knap så nemt, og måske endnu mere smertefuldt, at udpege os selv som medskyldige i visse normativerende voldshandlinger. For at opsummere kan vi sige følgende om queerhedens mekanik som en regulerende ramme for biopolitik:

\section{At anse queerhed som en automatisk og} immanent overskridende størrelse medfører specifikke former for disciplinering og kontrol, hvilket konstruerer queer-liberale æressubjekter, som er foldet ind i livet (queerhed som subjekt), overfor de seksuelt patologiske og afvigende befolkninger, som er rettet mod døden (queerhed som befolkning).

\section{Indenfor denne forståelse af regulerende} transgression, fungerer queer som et alibi for meddelagtighed sammen med alle mulige andre identitetsnormer såsom nation, race, klasse og køn, som uforvarende lokkes med i hvidhedens dominans.

3. At tillade meddelagtighed indikerer ikke, at queerhedens raciale, modstandsdygtige eller oppositionelle potentiale har fejlet, men kan være en muliggørende anerkendelse.

4. Det flyder dog over med dilemmaer om modstandens og meddelagtighedens glidende overgange, for end ikke intersektionelle modeller kan redegøre for de samtidige eller mangeartede tilstedeværelser af begge eller af mange.

\section{HVIDHEDENS DOMINANS}

Rey Chow refererer til Foucaults vark The Order of Things og foreslår, at "Foucaults diskussion om biopolitik kan læses som hans tilgang, hvor indirekte den end måtte være, til hvidhedens dominans i den moderne verden." Produktion af data, detaljer 
og beskrivelser gennem videnskabelig observation, klassifikation og taksonomi, som fører til detailstyring af information og kroppe, forsøger at "gøre verden til et genkendeligt objekt." Denne objektivering og finpudsning med det formål at styre og domesticere løber, ifølge Chow, parallelt med en stigende mystificering og tilsløring af de, som primært drager fordel af dette epistemologiske projekt: europæiske subjektiviteter. Denne samtidige specificering og abstraktion danner netop basis for adskillelsen af subjekter og objekter (og befolkninger), eller for Chow, adskillelsen af dem, der teoretiserer, og dem, der bliver teoretiseret over (Chow 2002).

Den nutidige "hvidheds dominans", som impliceres af biomagt, inkorporerer ifølge Chow en multiplikation af passende, multikulturelle, etniske kroppe, som er medskyldige i denne dominans. En del af indfangelsen af denne exceptionelle borger, etnisk eller ej, er den nøje forskelshåndtering: forskel inden for ensartethed og forskel, som indeholder ensartethed. Vi kan for eksempel bemærke, at den multikulturelle spredning af den kosmopolitiske etniske à la Chow har nogle udfordrende begrænsninger i forhold til klasse, køn og især seksualitet. Den smule accept, som liberal diversitet tilbyder i forhold til inklusion, er i høj grad formidlet igennem et eksklusionsherredømme: Det etniske subjekt er som regel heteroseksuelt, har oftest adgang til materiel og kulturel kapital (både som forbruger og som ejer) og er i de fleste tilfælde en mand. Det er disse foreløbige egenskaber, som adskiller en acceptabel etnisk (en exceptionel patriot for eksempel) fra en uacceptabel etnisk (en formodet terrorist). I mange tilfælde kan heteronormativitet være den mest afgørende af disse egenskaber, da visse orientalske queerheder (mislykket heteronormativitet eksemplificeret ved polygami, patologisk homoseksualitet) på forhånd er tilskrevet terroristkroppe. Multikulturaliseringen og heteroseksualiseringens dobbelte proces er afhængige af hinanden, hvilket
Susan Koshy betegner som en "forvandling fra race til etnicitet", en transformering, der drives frem af dyrkningen af et "hvidt privilegium som farveblindt meritokrati." (Denne transformering har også dannet inspiration for politiseringen af begrebet "people of color" (dvs. "ikke-hvide personer", red.)). Mens Chow ikke eksplicit diskuterer, hvorfor raciale rammer mister deres prominens (og beholder en nedgjort status) i forhold til markedsstyret etnicitet, tilføjer Koshy "indkvarteringen af nye indvandrere og den hvide etnicitets genopblusning" som overbevisende faktorer, der "skjuler funktionerne for race og klasse" i transnationale kontekster (Koshy 2001: 154, 156).

Disse "funktioner" involverer det, Koshy betegner som "klassefraktioner projiceret som mønsterminoriteten", der produceres gennem:

(...) ændrede demografier, klassestratifikation, ny indvandring og en global økonomi (...) hvilket derved åbner muligheden for opportunistiske alliancer mellem hvide personer og grupper af forskellige minoriteter efterhånden som omstændighederne tillader det (...) hvilket projicerer en repræsentation af inkludering, selvom det sætter skub i en politisk kultur af markedsindividualisme, der har legitimeret fratagelsen af understøttelse til dårligt stillede minoriteter med henvisning til nødvendigheden af den globale økonomi.

Koshy pointerer, at fraktionering fritager "en etnisk partikularistisk position" fra "undersøgelse" fordi dens afstand fra hvidhed som kulturelt fænomen ophæves via sin nærhed til "hvidhed som magt gennem (...) klasseforhåbninger," hvilket muliggør:

(...) en tilsyneladende mere sympatisk dispensation, som tillader kulturel forskel, selv når det fremmer politiske forbindelser mellem hvide og nogle ikke-hvide personer i forhold til visse kritiske emner såsom velfærd, positiv særbehandling og indvandringslovgivning. (Koshy 2001: 181, 155-156, 186) 
Så for det etniske subjekt med adgang til kapital, både i form af forbrug og ejerskab, er forførelsen af global kapital fremført via racialt hukommelsestab og andre former for forglemmelse. Denne fraktionering, eller nedbrydelse i fraktaler, grænser op til statsracisme i og med at den også promoverer den "censur inden for det biologiske kontinuum", som er nødvendig for på én gang at partikularisere og homogenisere befolkninger for kontrol (Foucault 2003: $255)$.

Hvidhedens dominans er for Koshy, såvel som for Chow, forankret i (neo)liberale ideologier om forskel - markedets, kulturelle og konvergenser af disse - som svarer til "fitness indenfor kapitalisme", og som i sidste ende lover "inkorporering i den amerikanske drøm.” (Koshy 2001: 193) At dette løfte altid fremstår som på nippet til at gå i opfyldelse, men aldrig helt lykkes, er hvad Sara Ahmed hentyder til i hendes argument, at "kærlighed kan være særligt afgørende i det tilfælde, at nationen ikke formår at indfri sit løfte om det gode liv." For Ahmed er national kærlighed en form for afventning, en dvælen som registrerer et "mindreværdsstigma", hvilket er indbegrebet af de indre virkninger af multikulturalisme (Ahmed 2005: 130-131; Bauman 2004: 104). Ugengældt kærlighed holder multikulturelle (og også homonormative) subjekter inden for nationalismens fold, mens xenofobiske og homofobiske ideologier og politikker bider sig fast. Igennem denne dynamik fremstår statens (og også markedets) velvilje som grænseløs, selvom den stadig er fuldt engageret i anti-homoxgteskabslovgivning og den amerikanske Patriot Act, for blot at nævne to eksempler. Derudover kaster markedet glans over staten ved at producere forbrugersubjekter (såvel som højtuddannede arbejdere), som simulerer (og oplever simulerede) affektive måder at tilhøre staten på, måder som dulmer angsten for ugengældt kærlighed. Således bevarer nationalstaten sine homofobiske og xenofobiske standpunkter, mens den udnytter sit uplettede image som inkluderende, forskelligartet og tolerant. Samtidig omdirigerer multikulturelle (og homonormative) subjekter deres loyalitet mod nationen via markedsprivilegier, en re-maskulinisering, som Heidi Nast kalder "markedsvirilitet” (Nast 2002: 878), der optræder som former for tilhør med nationen, og som formidler det ydmygende ved at vente på national kærlighed. Multikulturalisme gør sig medskyldig til hvidhedens dominans ved at reproducere det biopolitiske mandat til at leve via de korrekte befolkningsstatistikker; som set igennem en køns- og klasseoptik også ledsages af egenskaber og vurderinger af levealder, sygdom, sundhed, miljø, fertilitet og så videre. Via længslen efter national kærlighed bliver temporaliteten for multikulturelle mønster-minoritetsdiskurser fremtidig, en uendelig udskudt eller distraheret tilfredsstillelse, som afspejler biopolitikkens konstante march fremad, væk fra døden, hvor sikringen af i dag ledes tilbage via garantien for kvaliteten af livet $i$ morgen. Dette kræver køns- og seksualitetsnormativitet og reproduktionen af en hybrid multikulturel krops-politik i bytte mod lukrative muligheder inden for den globale økonomi.

Men er multikulturalisering utvetydigt heteronormativisering? Hvad er på spil i multikulturalismens strenge seksuelle og kønsmæssige dynamikker for dem, som kan fastholde den ugengxldte kærlighed og for dem, der ikke kan, eller ikke tør begynde at forestille sig muligheden for den? Man kunne konkludere på forhånd, at multikulturalisme som heteronormativisering fungerer som en regulering af seksuelle og kønsmæssige relationer og personificeringer magen til dens kontrol og udelukkelse baseret på klasse. Men historien for kapitalistiske udviklings- og familieformer (skiftet fra subsistensarbejde til lønnet arbejde i slutningen af 1800-tallet og starten af 1900tallet, som gav mulighed for mandlige, homoseksuelle, urbane subkulturer) indikerer, at kapitalisme er ambivalent: selve kapitalis- 
mens funktion, repræsenteret ved den heteroseksuelle kernefamilie som afgørende for arbejdskraftsreproduktionen, nedgraderingen af kvinder til gratis arbejdskraft $i$ hjemmet eller som underbetalte overskudsarbejdere og familien som den fundamentale sociale intimitetsenhed, der medierer arbejdsverdenens brutaliteter, er alle faktorer, som har gjort det muligt for (primært hvide, mandlige) arbejdere at forme alternative seksuelle fælleskaber, slægtskabsforbindelser og netværk (D'Emilio 1983: 100113). Både konsolidering af og brud med traditionelle heteroseksuelle familieformer er mulig, men i vores nutidige globale økonomi er den nødvendige mobilitet, som det også var tilfældet tidligere, begrænset af race, etnicitet, køn, klasse, og statsborgerskab. Som Ann Pelligrini skriver, "Opfindelsen af homoseksualitet var også samtidig opfindelsen af heteroseksualitet, og familien er ændret fra et produktionsområde til et forbrugsområde" (Pellegrini 2002: 137).

I forlængelse af Koshys pointe om "politisk kultur om markedsindividualisme" er det adgangen til kapital - "markedsvirilitet" - der formidler et nationalt tilhørsforhold og muligheden for at blive foldet ind i livet for multikulturelle etniske subjekter, homonormative subjekter og måske endda for de subjekter, der befinder sig i skæringspunktet mellem de to (Koshy 2001: 155-156). For det etniske subjekt er heteronormativitet styret af nationalstaten, men til forhandling via markedet i form af iøjnefaldende forbrug og højtuddannet arbejde: for det homonormative subjekt er hvidhed styret af staten, men til forhandling på markedet, igen både i form af forbrug og arbejde. Den queer eller homonormative etniske figur er nødvendig for at homonormative miljøer kan fremstå som forskelligartede (men som en forskel i kultur fremfor en repræsentation af kapital), og for at etniske og racialiserede indvandrermiljøer kan fremstå som tolerante (markeret som en indgang til en alternativ livsstil fremfor kapitalens ensartethed). Ironisk nok er det queer etniske subjekt og- så markør for homofobien (og påstanden om at homoseksualitet reflekterer vestlighed) i hans eller hendes raciale/etniske/ indvandrermiljø, når subjektet befinder sig $\mathrm{i}$ homonormative rum, i højere grad end en markør for racismen i homonormative miljøer, når han eller hun befinder sig $\mathrm{i}$ sit hjemmemiljø. (Det skyldes muligvis, at den velgørende [amerikanske] stat til dato har givet flere indrømmelser til etniske subjekter - en foldning ind i livet - end til homoseksuelle subjekter, i hvert fald i form af borgerrettigheder og på den historiske bane).

Identitetsfaktionering, -fraktionering og fraktalisering er en yndet aktivitet hos kontrolsamfund, hvorved subjekter (de etniske og de homonormative) orienterer sig som subjekter $\mathrm{i}$ form af deres afstandtagen fra og disidentificering med andre udenforstående subjekter til fordel for konsolidering med priviliegieakser. Det queer og homonormative etniske subjekt er en vigtig fraktal i disaggregeringen af korrekte homoseksuelle subjekter, da det tilslutter sig den hvide dominerende befolknings rækker til fordel for perverterede seksuelle befolkninger. Som med klassefraktionen, der projekterer en mønsterminoritet, ser vi her en klasse-, race- og seksuel fraktion projekteret til markedet $\mathrm{i}$ form af den homonormative homoseksuelle eller queer forbruger. Dette er en forbruger uden slægt, den bedste slags, projekteret til staten som reproducent af heteronormer, hvor relationer med hvide nationale hetero- og homonormative kroppe trumfer begæret efter queer forbindelser på tværs af klasse, race og statsborgerskab. Men hvad med racialiserede indvandrere eller ikke-hvide personer, som falder udenfor klasseparameteret om den etniske mønsterminoritet eller den homonormative, eller som bebor skæringspunktet mellem de to: den ikke-hvide queer (indvandrer)? Som Lisa Duggan påpeger, har neoliberalismens privatiserende dagsorden siden 1970erne nedbrudt en allerede minimal velfærdsstat (Duggan forthcoming). Hun bemærker, at nedskæringer på velfærd 
næsten giver mandat til heteroseksuelt $æ g-$ teskab; denne nedskæring, som velfærdsreformen fra 1996 (The Welfare Reform Act) er indbegrebet af, resulterede også i en rækker politikker, som forbandt promoveringen af heteroseksuelt xgteskab med velfærdsreformer, da det producerede mere stabile, traditionelle slægtskabskonfigurationer, en "privatiseringspolitik" af heteroseksuelt ægteskab. 25

Duggan pointerer, at bortset fra den moraliserende dagsorden fra grupper, der fremhæver "familieværdier", er der åbenlyse økonomiske fordele for staten i at tilskynde heteroseksuelt xgteskab. Moraliserende argumenter, forskansede under en overskrift om kultur, skjuler desuden økonomisk udnyttelse:

Indsatsen for at promovere ægteskab blandt befolkninger med lav indkomst virker på et retorisk niveau ved at flytte skylden for økonomisk modgang til de fattiges æegteskabspraksisser og væk fra et tab af arbejdspladser, velfærd og statsydelser. (Duggan forthcoming)

Og disse ægteskabspraksisser er således kodet som problematiske kulturelle og raciale afvigelser (polygami, matriarkat, kønssegregering) eller kodet som fiaskoer på grund af kulturelle og raciale egenskaber ("den sorte velfærdsdronning”). På samme måde hviler indvandrerpolitik på familiesammenføring og sponsorering af familiemedlemmer for ikke at tale om afhængigheden af familien, når det kommer til muligheden for arbejde, bolig, sprog og på nødvendige miljøer og religiøse netværk, som hjælper til kulturindlæring og værner mod racistiske og klassediskriminerende statspraksisser og hverdagsracisme.

Vi ser her alle komponenterne i konstruktionen af diskursen om indvandrerbefolkninger og ikke-hvide miljøer, der handler om en mere åbenlys misbilligelse af homoseksualitet og en mere dybt forankret homofobi, en homofobi der er konstrueret som korrekt konservativ og traditionel, når det tjener det politiske højre og statens interesser, og konstrueret som ukosmopolitisk og håbløst provinsiel, når det kan opildne anti-indvandrer-, anti-terror- og anti-velfærdsdiskurser. Men heteronormativ multikulturalisme og homofrigørelse er også rammer, der står i gæld til opfattelsen af indvandrerfamilier og ikke-hvide miljøer som mere homofobiske end hvide mainstream amerikanske familier. Betegnelsen "homofobisk kultur" udelader effekten af økonomisk ulighed og forskellen mellem kosmopolitisk etnicitet og patologisk racialisering, et element af neoliberalismens reproduktion af adskillelsen af økonomisk retfærdighed og identitetspolitik. ${ }^{26}$ Når det virker håndgribeligt eller lokaliserbart, empirisk og erfaringsbaseret, producerer udpegelsen af homofobi en geopolitisk kortlægning af neoliberale magtrelationer i skikkelse af kulturer af seksuel udfoldelse og undertrykkelse. Debatter om, hvilke miljøer, lande, kulturer eller religioner, der er mere, mindre, lige så, ens eller forskelligt homofobiske, mangler en mere kritisk vurdering af betingelserne for mulighed og umulighed, betingelser i forhold til økonomiske incitamenter, velfærds- og indvandrerpolitik, og racialt hierarki, frem for en distraheret eller uengageret opfattelse af kultur i sig selv. Homoægteskaber for eksempel er ikke blot et krav om ligestilling med heteroseksuelle normer, men også - og vigtigere, et krav om genetablering af hvide privilegier og rettigheder - ejendomsret og arveret især - mens homoægteskab og civilt partnerskab for andre er drevet af et seriøst behov for sundhedspleje. For George W. Bush gav modstanden mod homoxgteskaber i løbet af valgkampen i 2004 anledning til ellers utænkelige fotograferingsmuligheder i afroamerikanske kirker, hvilket føjede til højrefløjens strejftog ind i de ikke-hvide kirkemiljøer. ${ }^{27}$ Højrefløjen har brug for fattige indvandreres arbejdskraft i sin hegemonisk ideologiske base - familieværdier, trosbaserede initiativer, modstand mod hom- 
oægteskaber, modstand mod homoseksuelles ret til at adoptere, modstand mod rettighed til abort - og reproducerer de økonomiske og politiske betingelser for obligatorisk heteroseksualitet hvorved en grobund for homofobi skabes.

De fleste kritikker af homonormative politiske formationer peger $\mathrm{i}$ retningen af at køns- og slægtskabsheteronormer er delagtige $\mathrm{i}$ denne, men uden at påpege deres reproduktion af raciale og nationale normer (hvis en anden norm fremhæves er det som oftest klasse). Inden for heteronormativitetens dominans er der både implicitte, men også mere og mere eksplicitte interesser i hvidhedens dominans og de ledsagende statsborgerskabsprivilegier (homoxgteskaber er det mest relevante eksempel på dette), eller en variant af det, som Heidi Nast kalder "queer hvidt patriarkat" (Nast 2002: 881 ). I en meget omstridt artikel fastholder Nast, at "der er betydelig plads til diskussioner om hvidt patriarkalsk privilegium udenfor heteroseksuelle rammer." Hun redegør på skarpsindig vis for fordrivelsen af hvide heteroseksuelle mænd, der drager fordel af kapitalisme, til fordel for hvide homoseksuelle mænd, som:

(...) har et fortrin: Uden nogen nødvendige ideologisk-materielle forbindelser til biologisk-baseret familiehushold og de mobilitetsfriktioner, der følger med dette, deler de potentialet for de betydelige, omend ironiske, patriarkalske fordele, der er relationelle og som skærer på tværs af klasseskel (Nast 2002: 839). 28

Mens Lisa Duggan afviser at drage en parallel og sammenligne homonormativitet og heteronormativitet, da hun påpeger, hvordan dominerende sociale, politiske og økonomiske strukturer i sidste ende er umulige at overvinde på trods af et homonormativt privilegium (Duggan 2002: 17894), så peger Nast fra et neomarxistisk udgangspunkt på queer patriarkatets privilegier gennem "markedsvirilitet" og en faderlig kontrol med "reproduktionsprodukterne." Indfoldet i liv og livs-reproducerende har en aspirerende klasse af rige hvide homoseksuelle mænd, som kan simulere det biopolitiske mandat til at reproducere og regenerere, det måske bedre end deres heteroseksuelle modparter, måske endda meget bedre. ${ }^{29}$

Ved at implicere hvide lesbiske som en del af dette (faderskabs-?)scenarie via det globale transnationale adoptionskredsløb skriver David Eng:

[Transnational adoption] er blevet en populær og holdbar mulighed, ikke kun for heteroseksuelle, men også - i højere grad - for homoseksuelle par og enlige, som ønsker at (gen)konsolidere og (gen)besætte konventionelle familie- og slægtskabsstrukturer. (Eng 2003)

Han påpeger en historisk og politisk ændring fra diskurser og praksisser om afstandtagen til homofobiske familier til måder at sammensætte normer for homoseksuelt slægtskab og pointerer: “Bøsser og lesbiske er ikke længere undtagelser i forhold til familie- og slægskabsstrukturer”. Igennem en læsning af en John Hancock reklame, hvor to hvide amerikanske lesbiske kvinder følger deres ny-adopterede kinesiske datter igennem immigrationskontrollen og toldvæsnet i en større amerikansk lufthavn, påpeger Eng, at hvide, amerikanske, lesbiske kvinder med kapital er en "voksende niche-forbrugergruppe". Ved at stille spørgsmål ved "multikulturalismens etik" og ikke mindst fleksibel akkumulering, global kapital og udnyttelse, som er iboende i den nutidige etablering af "den nye globale familie", overvejer Eng:

Hvordan dette respektable lesbiske par med penge positioneres som de idealiserede beboere af en mere og mere acceptabel homoseksuel version af kernefamilien? (Eng 2003: 1, $6,7,3,7$ ) 
Hans argument antyder, at kinesiske adoptivbørn (og andre nationaliteter og etniciteter, som ikke er sorte) er blevet, og er nødt til at blive gjort til, surrogater for hvide børn.

Queer liberalisme omfavner disse diversitetspladser igennem, hvad Chow kalder "det hvide liberalistiske alibi". Med henvisning til Robyn Wiegman skriver hun om:

den særlige konstruktion af det nutidige, politisk korrekte, hvide subjekt, som forestiller sig, at det allerede succesfuldt har afskåret forbindelsen til sin kulturs tidligere mere brutale former for racisme. (Chow 2002: 14) 30 $^{3}$

At blive fritaget fra en kritik af ens egne magtmanipulationer er, hvad der appellerer ved hvid liberalisme, fundamentet for hvidhedens dominans, hvilket ikke er en konservativ, racistisk konfiguration opsat på udryddelse, men snarere en subtil liberal konfiguration, der tilbyder en harmløs inklusion i livet. ${ }^{31}$ Disse to eksempler fra Nast og Eng tyder på, at den kapitalistiske reproduktive økonomi (i samspil med teknologi: in-vitro-befrugtning, sædbanker, kloning, kønsudvælgelse, genetisk testning) ikke længere udelukkende hviler på et absolut krav om heteronormativitet; en simulering af samme kan være tilstrækkelig.

En opsummering: Hvidhedens dominans, der gengiver både disciplinære subjekter og befolkningsnormer, er ikke strengt begrænset til hvide subjekter, selvom den er forbundet til en multikulturalisme, der er defineret og implementeret af hvidhed. De etniske personer hjælper hvid-hedsprojektet ved at tage del i globale økonomiske privilegier, som så inddeler dem i mindre grupper og sorterer dem væk fra de raciale alliancer, som ellers kunne skabe tilhørsforhold på tværs af klasse, selvom multikulturalismeprojektet samtidigt får dem til at virke som fuldstændige og autentiske repræsentanter for deres etnicitet. Hvidhedens dominans er heller ikke bundet til heteroseksualitet, selvom det er bundet til heteronormativitet.
Det vil sige, at vi faktisk kan markere et specifikt historisk skift: Hvidhedsprojektet bliver hjulpet på vej af og har gavnet homoseksuelle befolkninger, som deltager i de samme identitetsmæssige og økonomiske hegemonier som de heteroseksuelle subjekter, der er medskyldige i dette overtag. Homonormativiteten hjælper heteronormativitetsprojektet ved at vende sig væk fra queer alliancer til fordel for en tilslutning til reproduktionen af klasse-, køns- og raciale normer. Heteronormativitetens dominans er derfor ikke forbundet til heteroseksuelle personer; og er heller ikke diskret begrænset til hvide personer, selvom den er forbundet til hvidhed. Det er her, den gode etniske person kommer ind i billedet. Mens den gode (heteroseksuelle) etniske person på nuværende tidspunkt har været modtager af "velviljetiltag" (Chow 2002: 11) dvs. er blevet foldet ind i livet, igennem flere årtier, så er den (hvide) homonormative person en mere nylig aktør i forhold til denne velvilje (borgerrettigheder og markedet), hvilket producerer tilhørsforhold, længsler og savn som nationalistiske affekter, men alligevel aldrig helt belønner sine fanger. Jeg bruger ekstra kræfter på disse stive fortællemodeller, mens jeg er opmærksom på den farlige forening af deskriptive og prædeskriptive narrativer, for at belyse fremstillingen af figurer (og fællesskaber) og deres medfølgende mytologier. Tilsammen udspiller og spilles disse figurer sammen for at holde sammen på det dødbringende binære par, der er dukket op i post-borgerrettighedsæraen i lovgivende, aktivistiske og videnskabelige cirkler: Den homoseksuelle anden er hvid, den raciale anden er heteroseksuel.

\section{Queer Nekropolitik}

I 1992 kritiserede Judith Butler Foucaults Seksualitetens historie for $\sin$

(...) ønsketænkningskonstruktion: døden er effektivt ekskluderet fra den vestlige modernitet, konstrueret bagved den som en historisk 
mulighed, overhalet eller konstrueret udenfor den som et ikke-vestligt fænomen (Butler 1993).

Hun beder os i stedet reevaluere biopolitiske investeringer $i$ at fremme livet ud fra homoseksuelle kroppe, som historisk set har været følelsesmæssigt investeret i døden, især queer kroppe ramt af eller truet af HIV-pandemien (Butler 1993: 85). For Foucault er den moderne biomagt, som dukkede op i slutningen af det 18. århundrede, håndteringen af liv - distributionen af risiko, mulighed, dødelighed, chance for liv, helbred, miljø, livskvalitet - og den forskelligartede investering af og i livets imperativ. Inden for biomagten er dødens udbredelse ikke længere den centrale bekymring for staten; det er derimod afværgelsen af døden. Dyrkelsen af livet falder sammen med den suveræne ret til at slå ihjel, og døden bliver blot til noget refleksivt, et biprodukt, en sekundær effekt af det primære mål og de kræfter, som dyrkes af og til livet. Døden er aldrig det primære fokus; den er en negativ oversættelse af nødvendigheden ved at leve og forekommer kun igennem bevægelsen mod at fremme livet. Døden bliver til en form for følgeskade i jagten på livet.

Distanceringen fra døden er modernitetens fejlslutning, en hallucination som muliggør biopolitikkens uhindrede arbejde. I Society Must Be Defended skriver Foucault:

Døden var ikke længere noget, som pludselig slog til midt i livet, som ved en epidemi. Døden var nu noget permanent, noget som glider ind i livet, konstant gnaver i det, formindsker det og svækker det (Foucault 2003: 244).

Butler omsætter den historiske ramme for Foucaults udarbejdelse af biomagt til en kontekst bestående af en nuværende politik om liv og død og bemærker ironien ved Foucaults egen tidlige død i 1984 på grund af AIDS, som på det tidspunkt var en epi- demi på nippet til sin eksponentielle detonering (Butler 1993: 81-98). På den måde returnerer Butlers analyse fra 1992 kroppen til døden, især den queer krop ramt eller truet af HIV-virussen. 32

Med en lignende protest, selvom den bunder i de tilsyneladende inkongruente forhold for koloniale og neokoloniale besættelser, retter Achille Mbembe vores opmærksomhed fra biopolitik, til hvad han kalder "nekropolitik". Mbembes analyse sætter fokus på døden som afkoblet fra projektet med livet - en direkte relation til at slå ihjel, som gør enhver hallucinerende fornægtelse af døden i moderniteten umulig - ved at spørge:

Er begrebet biomagt tilstrækkeligt for at redegøre for de nuværende måder, hvorpå det politiske, under dække af krig, modstand eller kampen mod terrorisme, gør drabet på sine fjender til sit primære og absolutte mål?

(Mbembe 2003: 12)

For Foucault er massakrer bogstaveligt talt vitale begivenheder (Chow 2002); for Mbembe er de beviser på biomagtens brutale tilskyndelse til livet.

I et millisekund har vi en sær sammenblanding og kompleksitet, som fordriver nekropolitik på en dobbelt måde: Først af biopolitiske magtantenner og derefter af den teoretiker, der beskriver dem. Ved at arbejde for det liberale demokratis rationelle politik nægter biopolitiske magtområder døden indenfor sig selv og for sig selv; døden er således afvist i kraft af sin egen sanktion. I Seksualitetens historie nægter Foucault, der selv er indfanget $\mathrm{i}$ biopolitikkens mekanisme og et disciplinært biopolitisk subjekt, dødens eksistens indenfor biopolitik. Men i Society Must Be Defended fastholder han, at "den gradvise diskvalificering af døden" i biopolitiske levende regimer stigmatiserer døden som "noget der skal gemmes væk. Det er blevet den mest private og skamfulde ting (det er således ikke sex så meget som døden, der er blevet tabu nu)". Denne privati- 
sering af døden, påpeger Foucault, signalerer, at i forsøget på at optimere livet "anerkender magten ikke længere døden. Magten ignorerer bogstavelig talt døden" (Foucault 2003: ).

Mbembes “dødsverdener" og "levende døde" kan på den anden side hænge sammen via et totaliserende narrativ om kvælningen af livet gennem de almægtige kræfter forbundet med at slå ihjel (Mbembe 2003: 12). Over for en daglig nekropolitisk vold, lidelse og død tordner biopolitikkens vilje til at leve videre, distribueret og redistribueret i dagligdagsbagateller, som noget ikke kun individuelle subjekter, men også befolkninger har kapacitet til: sundhed, hygiejne, miljø, medicin, forplantning og fødselsrate (og dermed fertilitet, børnepasning, uddannelse), dødelighed (udskydningen af døden, forlængelsen af livet), sygdom ("formen, naturen, udbredelsen, varigheden og intensiteten af en befolknings mest almindelige sygdomme" for at regulere arbejdsproduktionen og produktiviteten), forsikring, sikkerhed. Disse "sikkerhedsteknologier" promoverer et beroligende samfund, "alt i alt en balance, som fremmer helhedens sikkerhed mod indvendige farer", og er således impliceret i racens forbedring via rensning samt opblusning og regenerering af ens race (Foucault 2003: 249, 257).

Mens spørgsmål om reproduktion og regenerering er centrale for studiet af biopolitik, så har queer akademikere underligt nok været modstandere af den foucauldianske forståelse af biopolitik og koncentrerer sig hellere om Seksualitetens historie med et fokus på kritikken af psykoanalysen og repressionshypotesen, samtidig med at de implicit og ofte eksplicit fejer studiet af race $\mathrm{i}$ baggrunden. Rey Chow bemærker akademikeres manglende evne til at læse seksualitet gennem en biopolitisk ramme som symptomatisk for en modernistisk hældning mod en snæver homoseksuel/heteroseksuel binær identitetsramme, som favoriserer "samleje, sexhandlinger og erotik" fremfor "hele problematikken ved reproduktionen af det menneskelige liv, som i moderne tider altid er racialt og etnisk farvet" (Chow 2002: 67). ${ }^{90}$ Til det vil jeg tilføje den observation, at den stigende interesse for Seksualitetens historie i queer-studier primært skyldes interessen i Foucaults afstandtagen til "repressionshypotesen" og hans implicitte udfordring af freudianske psykoanalytiske narrativer, som fremhæver seksuel undertrykkelse som fundamentet for subjektivitet. (Med andre ord kan vi spore det genealogiske engagement i Seksualitetens historie som en splittelse: Akademikere, som studerer race og postkolonialisme, tager biopolitikken op, mens akademikere i queerstudier arbejder med at nedbryde repressionshypotesen. Dette er tendenser, ikke absolutter.) ${ }^{33}$ Det er dog også tilfældet, at akademikere, der studerer race og postkolonialisme, på trods af, at de forsker i intersektionen mellem race og seksualitet, på det seneste er begyndt at se på spørgsmål om seksualitet uden for heteroseksualitetens reproduktive funktion. ${ }^{34} \mathrm{Om}$ end Chows vurdering af vestlige tilbøjeligheder i retning af nærsynede gengivelser af seksualitet er overbevisende, så virker nedvurderingen af det seksuelle til udelukkende at tilhøre den (heteroseksuelle) reproduktion i sidste ende utilfredsstillende. I Chows tilfælde gør dette det muligt for hende at undlade at gøre sig overvejelser om de heteronormer, der insisterer på at forme parametrene for acceptable etniske personer. Desuden fokuserer forsøg på at bearbejde biopolitikkens effekt sjældent på ikke-normative seksualiteter, da de opfattes som irrelevante til trods for den afgrænsning af perversion og afvigelse, der udgør centrale komponenter for etableringen af netop de normer, som driver de biopolitiske interesser. ${ }^{35}$

Mange fortællinger om nutidig biopolitik fremhæver enten race eller statsracisme eller, som Judith Butler, resultatet af konstruktionen af kategorien "sex", uden at se på de to sammen (Butler 1993:; 8). I dette foretagende undersøger jeg den proces i 
nuværende amerikansk politik, hvor exceptionelle queer subjekter opsplittes fra queer racialiserede befolkninger, fremfor at tilbyde et overordnet paradigme af biopolitisk seksualitet, som løser disse dilemmaer. Ved at sætte race og seksualitet i centrum på samme tid i reproduktionen af relationer blandt levende og døde vil jeg fastholde spændingen mellem biopolitik og nekropolitik. Den sidstnævnte lader sin tilstedeværelse være kendt i den andens grænser og overskud; den førstnævnte maskerer sine mangfoldige forhold til død og drab for at muliggøre spredningen af den sidstnævnte. Denne distinktion og de spændinger, der ledsager den, har betydning af to årsager. For det første peger dét, at sammenholde de to koncepter, på et behov for også at behandle de mange rum for at afværge døden, hvad end de tager form som en optimering af livet eller som en mekanisme, der minimerer selve døden. Dette bio/nekro-samarbejde anerkender på et konceptuelt niveau biomagtens direkte involvering i døden, imens det forbliver forbundet til optimeringen af livet, samt nekropolitikkens nonchalance i forhold til døden, selv når den udpeger det at slå ihjel som sit primære formål. Ifølge Mbembe medfører nekropolitikken en stigende anatomisk, sanselig og taktil undertvingelse af kroppe - hvad enten det er de tilbageholdte kroppe på Guantánamo Bay eller det menneskelige spild af flygtninge, evakuerede, de levende døde, de døde levende, de forfaldne levende, eller dem, der lever en langsom død - idet den bevæger sig videre fra queer identitets- og synlighedsrammer til at adressere ontologi og affekt (Weber 2003: 11-40).

For det andet er det netop i intersektionen mellem liv og død, at vi finder forskellen mellem queer subjekter, som foldes (tilbage) ind i livet, og den racialiserede queerhed, som opstår i navngivningen af befolkninger, hvilket giver næring til en bevægelse mellem disciplineringen af subjekter og kontrollen af befolkninger. Dekonstruktionen af bio- og nekropolitikkens po- ler er ansvarlig for en bred vifte af afledte og udskudte dødsfald, for affald og forfald, men sætter også fokus på regenerering i forhold til reproduktion. Vi kan for eksempel komplicere den biopolitiske reproduktive biologismes centrale rolle ved at udvide terrænet for, hvem der reproducerer, og hvad der bliver reproduceret, noget, der løsner den altid allerede implicitte heteroseksuelle ramme, og undersøge hvordan produktionen af identitetskategorier som bøsse, lesbisk og endda queer fungerer servicerende for håndteringen, reproduktionen og regenereringen af liv, fremfor primært at blive forstået som implicit eller eksplicit udvalg til død. Ved at gå længere ind i Butlers fokus på, hvordan queer personer er blevet efterladt til døden, er det blevet på tide at spørge: Hvordan reproducerer queer personer livet, og hvilke queer personer bliver foldet ind i livet? Hvordan får de liv? Hvad giver de liv til? Hvordan bliver livet afvejet og disciplineret ind i subjekthed, fortalt ind i en befolkning og plejet til at leve? Medfører denne sekularisering af queer personer udsættelsen af død eller døden for andre, $\mathrm{og}$ i så fald for hvem?

Homonationalisme og biopolitik er en oversættelse af Jasbir Puars introduktion til værket: Terrorist Assemblages: Homonationalism in Queer Times (2007). Duke University Free Press, New York.

Oversat fra engelsk af Maja Brandt Andreasen, Ph.d.-stipendiat Communications, Media and Culture, University of Stirling

Redigeret af Morten Hillgaard Bülow, Camilla Bruun Eriksen, Louise Haj Brade og Matilde Lykkebo Petersen 


\section{NOTER}

1. Kaplan citerer Krauthammer, som er citeret i Eakin (2002).

2. De fleste diskussioner af “Don't Ask, Don't

Tell" diskuterer ikke racialiseringen af seksuelle subjekter i militæret eller nævner race som en afgørende faktor i kontrollen af ikke-normative seksualiteter. Når det nævnes, er det som oftest i form af en analogi over seksualitet som en tidligere succesfuld diversificering i militæret. Se for eksempel Belkin og Embser-Herbert (2002). For en evaluering af ikke-hvide personers plads i militæret, se Fears (2003). Fears skriver at: 38 procent af militærets 1,1 millioner rekrutter er etniske minoriteter, selvom de kun udgør 29 procent af befolkningen. I den største afdeling, hæren, er procentdelen af minoriteter tæt på at udgøre halvdelen af alle rekrutter med $45 \%$. Gruppen af afro-amerikanere alene udgør næsten 30 procent af hærens rekrutter ifølge Forsvarsministeriets statistikker fra 2000. Latinoer udgør ni procent af hæren og 12 procent af befolkningen. Sorte kvinder udgør næsten halvdelen af alle de kvindelige rekrutter i hæren (...) Procentdelen af minoriteter, som har meldt sig til hæren, overstiger langt procentdelen af minoriteter i uddannelser over high school-niveau, ifølge Det nationale center for uddannelsesstatistik.

3. Gregory Jay pointerer, at mens USA muligvis har "exceptionel magt" til effektivt at implementere sine former for nationalisme på et globalt plan, så er det “ikke exceptionelt i forhold til at skabe en fortælling om en nation, der har sin oprindelse i et særligt fysisk og kulturelt landskab, som angiveligt skaber grobund for et 'homogent' folk, som forenes i deres særlig forhold til sandhed, skønhed, godhed og Gud" (Jay 2003: 782).

4. Konstruktionen af Islam som en trussel mod kvinder er blevet styrket af muslimske forfatteres værker, såsom Irshad Manji. Se hendes America's Wild West (2005), for eksempel. Manji har fảet en beundrer i den homoseksuelle konservative Andrew Sullivan. Hans anmeldelse (2004) af hendes ikke så opfindsomt navngivne The Trouble with Islam, roser hende for at "gøre hvad så mange af os har længtes efter at se: Et angreb på det fundamentalistiske Islam selv for at tolerere den slags ondskab i sin midte. Og indefra." For en modanalyse se Dahir (2003).

5. Smeal (2001). For en videre diskussion af det problematiske forhold mellem Feminist Majority Foundation, Rawa og de afghanske kvinder, se Hirshkind og Mahmood (2002).

6. Den aften optrådte ligeledes Queen Latifah, Glenn Close, Jane Fonda, Marisa Tomei, Rosie Perez og Claire Danes som en del af "The Vagina
Monologues". Feminist Majority Foundation (2001).

7. Rapporter om ambivalente feministiske svar på begivenhederne den 11 . september 2001 og kampen mod terrorisme inkluderer Bunting (2001); Lerner (2001); Marks (2001); J. Goldstein (2002). For et eksempel på pro-krigs-feminisme se Stolba (2002). De feminister og feministiske analyser, som modsagde og stillede spørgsmål ved opbakningen til krigen inkluderer Abu-Lughod (2002); Thobani (2002); Joseph (2002); Henry (2002); Douglas (2002); Hyndman (2002). I en lidt anderledes tone stiller Catherine A. MacKinnon i State of Emergency spørgsmål ved, hvordan begivenhederne d. 11. september er blevet brugt til at promovere kampen mod terrorisme, mens hun samtidig ser begivenhederne den dag som en metafor for vold mod kvinder.

8. Cornell (2004: 314-15). Som det mest symptomatiske eksempel på denne forestilling brugte Bush-administrationen Laura Bush til at vise USAs angiveligt feministiske bekymringer; se Bumiller (2001).

9. Agamben påpeger, at i USA former det dialektiske forhold mellem presidentens autoritet og Kongressens autoritet fundamentet for undtagelsestilstandsdiskurser i Forfatningen (2005: 19). Denne dialektik er tekstuelt markeret af to sæt modstridende bekendtgørelser: Habeas corpus-akten kan blive suspenderet i tilfælde af oprør eller invasion, men det er uklart, hvem denne beføjelse tillægges; 2. Mens beføjelsen til at erklære krig og finansiere militæret ligger hos Kongressen, er præsidenten den øverstkommanderende over både hæren og søværnet, hvilket giver præsidenten en overvældende suveræn magt (2005: 20). Præsidentens autoritet maksimeres på mest frugtbar vis $\mathrm{i}$ krigstid, hvilket kan gøre tanken om "evig krig" forholdsvis appellerende, mens det også opfordrer til at tilknytte krigsmetaforer til ofte kontroversiel indenrigspolitik (krigen mod fattigdom, krigen mod stoffer (2005: 21).

10. For en kortsigtet oversigt over disse debatter se Kammen (1993). Et resumé af Edward Saids kritik af amerikansk exceptionalisme er at finde i Rowe (2004).

11. Irshad Manjis synspunkter er særligt ekstreme i denne forbindelse. Manji ophøjer USA som leder af den civiliserende tolerance og mulighedernes land, hvilket sætter "succesen" med muslimsk integration i kontrast til "fiaskoen" med muslimsk assimilering i Europa, og ser dette som et resultat af amerikanske kulturelle værdier uden at tage økonomiske forhold i betragtning. Dette afsnits diskussion af queer sekularisering er blevet til takket 
være samtaler med Jinthana Haritaworn, Adi Kuntsman, Catherine Sameh, Bahia Munem og Ethel Brooks.

12. Dahir (2004). Dahir rapporterer, at hans interviewperson "Mohammed" "siger, at han nogle gange føler sig ligeså meget udenfor i homomiljøet, fordi han er muslim, som han gør i det muslimske miljø, fordi han er homoseksuel, især siden terrorangrebene 11. september." Centralt står artiklens diskussion af foreningen af queer sorte muslimer og queer arabiske muslimers interesser på baggrund af de stædige og vedholdende diskurser om hæmningsløs homofobi i både sorte og muslimske kulturer og miljøer. Dahir fremlægger en læsning af forholdet mellem islam og homoseksualitet som komplekst frem for modstridende. Et eksempel på det er Mohammeds behov for ikke at identificere sig som homoseksuel, mens han studerer islam, mens han samtidig forklarer sin forståelse af islam som "hverken mere eller mindre homofobisk end andre religioner."

13. Dahir (2002: 93); Quinn (2001). Quinn siger: "Mens vestlige samfund tilbyder en lang række spirituelle alternativer til homoseksuelle kristne, jøder og andre, som ønsker at bevare en form for religiøs tro, har islam traditionelt set lukket døren for selve idéen om homoseksualitet." Dette ahistoriske udsagn (hvornår begyndte vestlige samfund at "tilbyde en lang række spirituelle alternativer til homoseksuelle kristne, jøder og andre"?) har ingen kilder. Det afviser tidligere og fortsatte homofobiske praktikker i kristendommen og jødedommens navn såvel som eksistensen af praktiserende queer muslimer.

14. For et eksempel på mandlig homosocialitet $=$ homoseksualitet, se Smith (2002). Se også Anderson (2002); Bradley (2004); Reynolds (2002) og Stephen (2002). En anden fortolkning er, at homoseksualitet altid allerede forstås som mulig indenfor visse homosociale rum; fejllæsningen ligger dermed ikke $i$ at sammenligne homosocialitet med homoseksualitet, men i den første antagelse at homosocialitet fungerer som et dxkke for homoseksualitet. For en diskussion af det mangesidede forhold mellem islamisk lov, muslimske nationer og kulturer og kvindelig homoseksuel seksualitet, se Ali (2002). Om de vestlige mediers problematiske rapportering af en pashtunsk mandlig seksualitet, se Skier (2004). Skier pointerer, at "britiske og amerikanske nyhedsmedier ... tilbød en ufuldstændig, problematisk og sensationalistisk karakterisering af denne form for homoseksuel relation," og citerer artikler såsom Times of London-artiklen fra 5. oktober 2001 “Repressed Homosexuality?” og da Associated Press refererede til
Afghanistan som "Babylon med burkaer, Sodoma og Gomorra med sand." I LGBTIQ-medier påpeger Skier, at Planet Out "gør hvad de kan for at omfavne homoægteskaber i Afghanistan," mens "LGNY (New Yorks avis for bøsser og lesbiske) sørger for at distancere homoseksuelle identiteter fra denne form for relation." Ved hjælp af forskellige tilgange, pointerer Skier, arbejder begge nyhedsmedier frem mod "det samme mål, som er at promovere euro-amerikanske bøsse- og lesbiske identiteter" (2004: 17). For artikler citeret af Skier se Griffin (2001); Knickmeyer (2002).

15. Rapporter om queer muslimer inkluderer Gay.com UK (2001); Bull (2001); Smith (2002). En tidligere tekst er Goldman (1999). Queer muslimske selvrepræsentationer inkluderer Alam (2002); og Frameline (2002). Sammen med AlFatiha er der Queer Jihad (2005). "Queer Jihad er den queer muslimske kamp for accept: For det første er det kampen for at acceptere os selv som værende præcis som Allah har skabt os. For det andet er det kampen for forståelse blandt muslimer generelt," ifølge deres hjemmeside (2003).

16. For en diskussion af Sharmas film se Hays (2004). Se også Hartley Film Foundation (2006); og In the Name of Allah (u.d.).

17. Se Mustikhan (2003). Beskrivelsen af forfølgelsen af palæstinensiske queers inkluderer udtalelsen "Rapporter om Nazi-agtig behandling af åbent homoseksuelle palæstinensere er almindelige". Det virker upassende at lave en sådan forbindelse mellem palæstinensere og nazister; for det første er det uklart, hvad "Nazi-agtig" betyder, og hvordan det er relevant for emnet, og for det andet positionerer det palæstinensere som sammenlignelige med de mest berygtede jødemordere, hvilket gør den israelske-palæstinensiske konflikt til en fortsættelse af holocaust.

18. For detaljer om palæstinensisk queer aktivisme se ASWAT-Palestinian Gay Women (2005), og Morcos (2004). WorldPride 2006 blev afholdt den 6.-12. august. Konservative kristne, jødiske og muslimske grupper protesterede imod arrangementet, og embedsmænd fra Jerusalem var også imod det, især borgmesteren Uri Lupolianski. Se Freedman (2006); Buchanan (2006). Det rapporteres, at en sådan protest tog form af foldere, som blev delt ud i ortodokse kvarterer, og som tilbød økonomisk kompensation til enhver, som "slog en sodomit ihjel" (DiGiacomo 2006). Krigen mellem Hezbollah og Israel, som fandt sted under WorldPride, fik skyld for drastisk at mindske fremmødet (fra de forventede flere tusinde deltagere til nogle hundrede). Krigen fik også skylden for, at paraden, som var planlagt til 10. August, blev aflyst: Politiet 
i Jerusalem nægtede at udstede den nødvendige tilladelse med begrundelsen, at man ikke ville være i stand til at garantere deltagernes sikkerhed på grund af manglende arbejdskraft, der var konsekvens af krigen (Wilcox 2006). Dette sker efter, at WorldPride 2005 i Jerusalem blev aflyst, fordi Israel havde trukket sig ud af Gaza. Jerusalem Open House, værtsorganisationen for WorldPride 2006, afholdt en demonstration ved en port mellem Jerusalem og Betlehem for at "lade (palæstinensiske medlemmer af Jerusalem Open House, som var afskåret fra at deltage i WorldPride-arrangementer) vide, at vi ikke havde glemt dem", ifølge et medlem af Jerusalem Open House (Zeesil 2006). Den allestedsnærværende Michael Luongo erklærer personligt, at protesterne den 10. (som blev afholdt i stedet for paraden) blev taget som gidsel af "anti-krigsaktivister" (2006).

19. OutRage! (2005a). For en kommentar til problematikken ved OutRage!'s tilgang, se Morcos (2004).

20. Mens de er dygtige til at finde sager om homofobiske muslimske gejstlige, så formår OutRage! ikke at offentliggøre eller diskutere britiske muslimske gejstliges fordømmelse af homofobi. Se Gay.com UK (2004). OutRage! lader til at fokusere overdrevet meget på muslimsk homofobi i lyset af reel vold udført af engelske hvide racister. For eksempel bombede hvide racister i 1999 homobaren the Admiral Duncan. To tidligere bombeangreb, muligvis udført af de samme gerningsmænd, havde engelsk-bangladeshiske og afro-caribiske miljøer som mål; NewsPlanet Staff (1999a). I stedet for at fokusere på græsrodsbevægelsers samarbejde, kritiserede OutRage! offentligt indenrigsminister Jack Straw for at mødes med medlemmer af homorettighedsgruppen StoneWall og kaldte det "splidskabende", fordi organisationen ikke var inkluderet; NewPlanet Staff (1999b).

21. Tatchell 1995. Peter Tatchell er Storbritanniens enmands-homorettighedsorganisation. Hans hjemmeside http://www.patertatchell.net har en liste af hans "Homo- og menneskerettighedskampagner" og den fulde udgave af "Peter Tatchells menneskerettighedsrapport 2004". Hans selvrefererende narcissisme (mest skamløst præsenteret i afsnittet "Billeder af Peter Tatchell"), som dominerer siden, indikerer, at Tatchell, som udtaler at hans "direkte handling"-kampagner er mere effektive end Amnesty Internationals arbejde, ser sig selv som en enestående befrier og missionær midt i et hav af ineffektive menneskerettighedsorganisationer. Det er værd at bemærke, at Tatchell tilsyneladende har bevæget sig væk fra OutRage!, da siden ikke længere eksisterer. Nu kan man finde ham på
"Peter Tatchell Human Rights Fund" og "Peter Tatchell: Gay and Human Rights Campaigns". 22. Som forløber for denne pressemeddelelse skrev Tatchell en artikel ved navn "Islamic Fundamentalism in Britain". Han benytter sig af lejligheden til at advare: "Islamisk fundamentalisme i Storbritannien er ikke begrænset til asiatiske og arabiske miljøer" og den "sorte militante Nation of Islam" er endnu en trussel mod queer personer. Et andet eksempel på opfattelsen af den trussel, som muslimske mænd udgør overfor homoseksuelle ses i dækningen af kampen mod hate crimes begået mod det hollandske LGBTQ-miljø, hvor "mænd af marokkansk afstamning", er den eneste gruppe, der nævnes som gerningsmændene bag disse homofobiske hadforbrydelser. Se PlanetOut Network (2005). Diskussioner af muslimsk homofobi i Europa forbindes ofte til muslimske indvandreres manglende evne til at lade sig assimilere, eller med ovennævnte artikels egne ord "integrere". I disse formuleringer forbindes homofobisk vold begået af arabere/muslimer/udlændinge automatisk til deres religion, mens vestlig integration tilbyder en tolerant kultur, hvor LGBTQ-personer ikke behøver frygte vold.

23. Dette fænomen er ikke begrænset til queer politik, som Scroggins (2005) bemærker: "Hvad der lader til at være et udbredt fænomen i hele Europa er, at nogle feminister allierer sig med højreorienterede imod indvandring og mod deres tidligere multikulturelle allierede på venstrefløjen. De får følgeskab af homoaktivister, som bebrejder muslimske indvandrere for det stigende antal overfald på homoseksuelle par".

24. OutRage! (2005b). Pressemeddelelsen starter med et citat af lederen af OutRage! Peter Tatchell: "Mødesteder for homoseksuelle kan blive udsat for bombeangreb af islamiske terrorister. Alle homobarer og -klubber bør indføre kropsvisitationer og tjek af tasker. Muslimske fundamentalister har et voldeligt had mod homoseksuelle mænd og kvinder. Dette er ikke en tid, hvor man kan være tilfreds med tingenes tilstand." Tatchell benytter sig af den samme frygttaktik, som er blevet en alt for velkendt del af kampen mod terrorisme, ved at opfordre homoseksuelle til at beskytte sig mod den muslimske trussel. Advarslen er særlig interessant, fordi den blev offentliggjort samme dag, som USA kendte Eric Rudolph skyldig i bombeangrebet mod homobaren Otherside Lounge i Atlanta, Georgia i februar 1997 samt bombeangrebene mod to abortklinikker og mod de Olympiske Lege i Atlanta i 1996. Domfældelsen mod Rudolph lader ikke til at have fremprovokeret samme respons blandt amerikanske LGBT-organisationer, som 
OutRage! respons gjorde. I stedet for at opfordre til at lægge queer-miljøet for had, et had som formodes at være funderet i amerikansk kristen konservatisme, rapporterer artiklen, at en talsmand for the Human Rights Campaign (Jay Smith Brown), svarede følgende, da han blev spurgt, om religiøse konservative på nogen måde kunne holdes til ansvar for Rudolphs vold: "Vi er nødt til at opfordre til en dialog baseret på ærlighed og forståelse fremfor had og vredesudbrud. Begge sider af debatten bør være ansvarlige for at debatten tager form af en positiv dialog." Se Curtis (2005).

25. Duggan 2004: 16. Denne privatisering kan ses i den eksplicitte promovering af æateskab i Bill Clintons velfærdsreform fra 1996 og udvidet i Bush's 1,5 milliarder \$ pakke "som blev brugt til at ansætte konsulenter og tilbyde kurser i ægteskabelig harmoni”. Kvinder er på den måde afhængige af mænd for økonomisk støtte, mens de tager sig af andres behov: børn og ældre eller handicappede familiemedlemmer. Disse husstande bestående af gifte par er således fritaget for ansvaret for velfærden i husstande med enlige forældre, mens ubetalte kvinder bliver ansvarlige for adskillige sociale ydelser (børnepasning, hjemmepleje), og således er velfærdsydelserne basalt set blevet privatiseret.

26. Duggan (forthcoming), se også Audre Lourde Project (2004). Forskningen udført af Audre Lourde Project undersøger forholdet mellem heteroseksualiseringen af indvandrerfamilier via familiesammenføringspolitik og velfærdsreformer. For en udførlig analyse af denne forskning se Reddy (2005).

27. For diskussioner af George W. Bush's forsøg på at vinde støtte blandt afroamerikanere via sin modstand mod homoægteskaber se Carnes (2004); og Knippenberg (2004).

28. Nast 2002: 839. Nasts brug af begrebet patriarkat virker lidt mærkeligt, da det er blevet voldsomt problematiseret af amerikanske ikke-hvide tredjeverdens feminister og poststrukturalistiske feminister, som forsøger at destabilisere begrebets universaliserende antagelser.

29. Nast argumenterer for, at den historiske kapitals akkumulering af hvide mandlige privilegier muliggør en formodet virilitet for hvide homoseksuelle mænd "via et differentielt profitabelt engagement i markedsbaserede investeringer og transaktioner i forhold til kvinder og ikke-hvide personer, og i nogle tilfærlde endda heteroseksuelle, hvide elitemænd". Mens denne evne til at forbruge ofte forklares som et resultat af "den generelle mangel på personer, der er afhængige af dem”, så bemærker Nast, at biologisk reproduktion kan ud spille sig via $\mathrm{k} ø \mathrm{~b}$ af livmødre og transnational adoption. "Groft sagt så er faderskab noget, der følger med genvindingen af forsørgerstatussen og faderlig autoritet" (2002: 878, 879-80).

30 . I en anden kritik af queer liberalisme problematiserer Paola Bacchetta dominante konfigurationer af "transnational queerhed", som favoriserer forbruger-queers (queer turisme), queer akademikere ("antro-queer studier" for eksempel) og aktivist-queers (dem, som er involveret i globalt NGOarbejde, og som er "nationale subjekter, som taler i transnationale fora") (2002: 951).

31. På den selvudnævnte politiske venstrefløj er for eksempel Michael Moores Fabrenheit 911 fyldt med "islamofobiske skygger", som knap nok bemærkes blandt hans brølende polemik mod (G.W.) Bush-administrationen (Chari 2004: 908). Et andet eksempel er den homoseksuelle manuskriptforfatter Tony Kushners anmelderroste Homebody/ Kabul, som er skrevet før 11. september 2001 og foregår i New York City og San Fransisco kort tid efter, og som Patrick Corcoran har kaldt et eksempel på "Orientalisme med et liberalt ansigt". Se Corcoran (2003). Se også Minwalla (2003).

For nogle sektorer hviler den politiske venstrefløjs fornyede energi på reproduktionen af raciale skel mellem hvide personer og ikke-hvide personer, som af netop de årsager fornægter interpellationen af en fabrikeret venstrefløj. Knap så mainstream fora har brugt race ikke kun som en kritisk intervention i hvide anti-krigsmiljøer, men også som en primær organiserende struktur til at have overopsyn med steder som kvarterer, miljøer, kirke-baserede fællesskaber og undervisningsfora. Men mange af disse tiltag har en tendens til at forstå deres valgkredse som udelukkende heteroseksuelle. Se Bloom et al. (2003). Brevet starter med "Kære søstre og brødre".

32. I mit forsøg på at udrede indholdet af nutidig biopolitik i terrorismens tidsalder har jeg hentet information fra det nylige teoretiske arbejde foretaget af postkoloniale og transnationale akademikere, inklusive Inderpal Grewal (biopolitikken og geopolitikkens konvergenser i neoliberalismen), Michael Hardt og Antonio Negri (biopolitisk produktion), Patricia Clough (biopolitiske affektive økonomier), Gilles Deleuze (biopolitiske kontrolsamfund) og Achille Mbembe (biopolitik og nekropolitik): Grewal 2005; Hardt og Negri 2000; Deleuze 1997; Deleuze og Guattari 1987; Clough (forthcoming); Mbembe 2003. For mit udgangspunkt har jeg lånt en del af et spørgsmål stillet af Eugene Thacker, "Hvordan forstår vi Foucaults koncept om biopolitik efter Foucault? Hvordan er konceptet om biopolitik ændret inden 
for den nuværende kontekst?”(2005: 22). Men jeg lader mig også inspirere af den konference, som Patricia Clough afholdt på CUNY Graduate Center i New York City i marts 2006 ved navn "Beyond Biopolitics".

33. For en overbevisende analyse af Foucaults genealogiske udlægning af analyser af race og sex og implikationerne, når de to overlapper, se McWhorter (2003).

34. For eksempler på postkolonial forskning, som tager højde for seksualitet udover reproduktiv heteroseksualitet, se Hayes 2000; McClintock 1995; samlingen Postcolonial and Queer Theories, redigeret af Vanita; Patel (2004); Arondekar (2005a) og (2005b); Najmabadi (2005).

35. Se Stoler (1995). Stolers arbejde er banebrydende i sin diskussion af biopolitik og kolonialisme især i forhold til brugen af kolonier som øvesteder for, hvad Foucault identificerer som biopolitik i Europa. Se side 129, fodnote nr. 93 for Stolers kommentar om det centrale ved heteroseksualiteten i hendes argument, det "onde" ved homoseksualitet som en racialiserende diskurs og arkivressourcers død, som kan sætte gang i en dybere læsning af ikke-normative seksuelle figurer såsom den "perverse voksne".

\section{LITTERATUR}

- Abu-Lughod, Lila (2002): Do Muslim Women Really Need Saving? Anthropological Reflections on Cultural Relativism and its Others, in: American Anthropologist, 104 (3): 783-90.

- Adam, Barry D. (2003): The Defense of Marriage Act and American Exceptionalism: The 'Gay Marriage' Panic in the United States, in: Journal of the History of Sexuality, 12 (2): 259-76.

- Agamben, Giorgio (1998): Homo Sacer: Sovereign Power and Bare Life. Translated by Daniel HellerRoazen. Stanford University Press, Stanford. - Agamben, Giorgio (2005): The State of Exception. Translated by Kevin Attell. University of Chicago Press, Chicago.

- Ahmed, Sara (2004): Affective Economies, in: Social Text, 22 (2): 117-39.

- Ahmed, Sara (2005): The Cultural Politics of Emotion. Routledge: London.

- Alam, Faisal (2002): Remembering September 1lth as a Queer Muslim, in: The Gully, September 11, 2002. http://www.thegully.com (accessed June 11,2006$)$.
- Ali, Kecia (2002): Special Focus: Islam: Same-Sex Sexual Activity and Lesbian and Bisexual Women, in: The Feminist Sexual Ethics Project, Brandeis University. December 10, 2002. http://www. brandeis.edu (accessed June 11, 2006).

- Anderson, Jon Lee (2002): Letter from Afghanistan: After the Revolution, in: New Yorker, January $28,2002,62-69$.

- Arondekar, Anjali (2005a): Border/Line Sex: Queer Postcolonialities and How Race Matters outside the United States, in: Interventions: International Journal of Postcolonial Studies, 7 (2): 236-50.

- Arondekar, Anjali (2005b): Without a Trace: Sexuality and the Colonial Archive, in: Journal of the History of Homosexuality, 14 (1-2): 10-18.

- ASWAT-Palestinian Gay Women (2005): Parade to the Wall: World Pride under Occupation, in: ColorLife!: 1, 4.

- Audre Lorde Project (2004): Communities at a Crossroads: U.S. Right Wing Policies and Lesbian, Gay, Bisexual, Two Spirit and Transgender Immigrants of Color in New York City. Audre Lorde Project: New York.

- Bacchetta, Paola (2002): Rescaling Transnational 'Queerdom': Lesbian and 'Lesbian' IdentitaryPositionalities in Delhi in the 1980s, in: Antipode: $A$ Radical Journal of Geography, 34 (5): 947-73.

- Bauman, Zygmunt (2004): Wasted Lives: Modernity and its Outcasts. Polity Press: Cambridge, Massachusetts.

- BBC News (2002): Obituary: Pim Fortuyn. May 6, 2002. http://news.bbc.co.uk (accessed June 25,2005 ).

- Belkin, Aaron \& Embser-Herbert, Melissa Sheridan (2002): A Modest Proposal: Privacy as a Flawed Rationale for the Exclusion of Gays and Lesbians in the U.S. Military, in: International Security 27 (2): 178-97.

- Bloom, Steve, et al. (2003): An Open Letter to Activists Concerning Racism in the Anti-War Movement, in: Colorado Campaign for Middle East Peace. February 13, 2003. http:// www.ccmep.org (accessed June 28, 2005).

- Bradley, John R. (2004): Saudi Gays Flaunt New Freedoms: 'Straights Can't Kiss in Public or Hold Hands Like Us.', in: The Independent, February 20, 2004, 34.

- Brown, Janelle (2002): A Coalition of Hope, in: $M s$, spring 2002, 65-76.

- Buchanan, Wyatt (2006): Broad Opposition to World Pride in Jerusalem, in: San Francisco Chronicle, July 26, 2006, A2.

- Bull, Chris (2001): Gay, Muslim, and Scared, in: The Advocate, October 23, 2001, 54. 
- Bumiller, Elizabeth (2001): First Lady to Speak about Afghan Women, in: New York Times, November 16, 2001, B2.

- Bunting, Madeleine (2001): Women and War: While the Media's Response to the Destruction in America Has Been Deafening, the Voices of Women Have Grown Strangely Quiet, in: Guardian (London), September 20, 2001, 19.

- Butler, Judith (1993): Sexual Inversions, in: John D. Caputo and Mark Yount (eds.): Foucault and the Critique of Institution, 81-98. Pennsylvania State University Press: University Park.

- Carnes, Tony (2004): Wooing the Faithful. September 28, 2004. http://www.christianity today.com (accessed June 15, 2005).

- Chari, Sharad (2004): F 9/11, a View from South Africa, in: Environment and Planning D: Society and Space, 22 (6): 907-10.

- Chow, Rey (2002): The Protestant Ethnic and the Spirit of Capitalism. Columbia University Press:

New York.

- Clough, Patricia Ticineto (forthcoming): The Affective Turn, in: Theory, Culture, and Society.

. Cohen, Cathy J. (1997): Punks, Bulldaggers, and Welfare Queens: The Radical Potential of Queer Politics?, in: GLQ: A Journal of Lesbian and Gay Studies, 3 (4): 437-65.

- Corcoran, Patrick (2003): Ego Tourism: 'Homebody/Kabul' Explores Life in Afghanistan, but Western Interests Still Prevail. [Review of Homebody/Kabul, by Tony Kushner]. Mark Taper Forum, Los Angeles. Los Angeles City Beat, October 9, 2003. http://www.lacitybeat.com (accessed June 12,2006 ).

- Cornell, Drucilla (2004): The New Political Infamy and the Sacrilege of Feminism, in: Metaphilosophy, 35 (3): 313-29.

- Curtis, Christopher (2005): Gay Bar Bomber Eric Rudolph Sentenced to Life. July 18, 2005. http://www.gay.com (accessed June 12, 2006).

- Dahir, Mubarak (2002): Queer and Muslim, in: San Francisco Pride Official Magazine, 2002, 91-93. - Dahir, Mubarak (2003): Proud of 'Intolerance.', in: Windy City Times, September 30, 2003. http:// www.windy citytimes.com (accessed June 11, 2006). - Dahir, Mubarak (2004): Gay Imam Will Reach Out to Gay and Lesbian Muslims, in: Temenos, September 6, 2004. http://www.temenos.net (accessed June 11, 2006). · Deleuze, Gilles (1997): Negotiations: 1972-1990. Translated by Martin Joughin. Columbia University Press: New York. - Deleuze, Gilles \& Guattari, Félix (1987): $A$ Thousand Plateaus: Capitalism and Schizophrenia. Translated by Brian Massumi. University of Minnesota Press: Minneapolis.
- D’Emilio, John (1983): Capitalism and Gay Identity, in: Ann Snitow, Christine Stansell, and Sharon Thompson (eds.): Powers of Desire: The Politics of Sexuality, 100-113. Monthly Review Press: New York.

- Derrida, Jacques (1994): Specters of Marx: The State of Debt, the Work of Mourning, and the New International. Translated by Peggy Kamuf. Routledge New York.

- Desai, Poulomi \& Sekhon, Parminder (2003): Red Threads: The South Asian Queer Connection in Photographs. Diva Books: London.

- DiGiacomo, Robin (2006): Hate Leaflets Don't Sway WorldPride Resolve. July 11, 2006. http: //www.gay.com (accessed September 5, 2006). - Douglas, Carol Anne (2002): NWSA Looks at September 11 and the War on Terrorism, in: Off Our Backs, 32 (9-10): 10-15, 45-48.

- Duggan, Lisa (2002): The New Homonormativity: The Sexual Politics of Neoliberalism, in: Russ Castronovo \& Dana Nelson (eds.): Materializing Democracy: Toward a Revitalized Cultural Politics, 175-94. Duke University Press: Durham.

- Duggan, Lisa (2004): Holy Matrimony!, in: The Nation, March 15, 2004, 14-19.

- Duggan, Lisa (forthcoming): Excerpt from The End of Marriage: The War over the Future of State Sponsored Love. University of California Press: Berkeley.

- Eakin, Emily (2002): Ideas and Trends: All Roads Lead to D.C., in: New York Times, March 31, 2002 , sec. 4 , p. 4.

- Eng, David L. (2003): Transnational Adoption and Queer Diasporas, in: Social Text, 21(3): 1-37. - Fanon, Frantz (1967): Black Skins, White Masks. Translated by Contance Farrington. Grove Press Books: New York.

- Fears, Daryl (2003): Draft Bill Stirs Debate over the Military, Race and Equity, in: Washington Post, February 4, 2003, A3.

- Feminist Majority Foundation (2001): Eve Ensler's Tribute to Afghan Women Is a Sold Out Success at Madison Square Garden. February 12, 2001. http://feminist.org (accessed June 11, 2006). - Foucault, Michel (2003): Society Must Be Defended, in: Lectures at the College de France, 19751976. Translated by David Macey. Picador: New York.

- Frameline (2002): I Exist: Voices from the Lesbian and Gay Middle Eastern Community, in: 26th San Francisco International Gay and Lesbian Film Festival 2002. http://www.frame line.org (accessed June 11, 2006).

· Freedman, Ina (2006): 'Jerusalem Will Be No 
More Holy If Gays Are Distanced from It.', in: Jerusalem Report, August 7, 2006, 64.

- Furuhashi, Yoshie (2004): A 'Clash of Civilizations,' Sending Pink Sparks Flying?, in: Critical Montages. Posted June 8, 2004. http://montages.blogspot.com (accessed June 17, 2005).

- Gay.com UK (2001): Gay Muslims Condemn U.S. Attacks, in: PlanetOut News, September 12, 2001. http://www.planetout.com (accessed June $14,2005)$.

. Gay.com UK (2004): U.K. Faith Leaders Unite, Urge Tolerance, in: PlanetOut News and Politics, September 26, 2004. http://www.planetout.com (accessed June 14, 2005).

- Goldman, David (1999): Gay Muslims, in: Southern Voice, August 19, 1999. Republished n.d. http: //www.flameout.org (accessed June 11, 2006).

- Goldstein, Joshua (2002): John Wayne and GI Jane, in: Christian Science Monitor, January 10, 2002, 11 .

- Grewal, Inderpal (2005): Transnational America: Feminisms, Diasporas, Neoliberalisms. Duke University Press: Durham.

- Griffin, Michael (2001): The Taleban: Repressed Homosexuality?, in: Times (London), October 5, 2001. http://www.freerepublic.com (accessed June 29, 2006).

- Hardt, Michael \& Negri, Antonio (2000): Empire. Harvard University Press: Cambridge, Massachusetts.

- Hartley Film Foundation (2006): In the Name of Allah. Updated February 28, 2006. http:// www.hartleyfoundation.org (accessed June 12, 2006).

- Hassner, Pierre (2002): The United States: The Empire of Force or the Force of Empire, in: Chaillot Papers, 54. Institute for Security Studies, European Union 46: Paris. http://www.iss-eu.org (accessed June 11, 2006).

- Hayes, Jarrod (2000): Queer Nations: Marginal Sexualities in the Maghreb. University of Chicago Press: Chicago.

- Hays, Matthew (2004): Act of Faith: A Film on Gays and Islam, in: New York Times, November 2, 2004, late ed., E3.

- Henry, Alice (2002): Trouble and Strife: Feminist Perspectives after September 11, in: Off Our Backs, 32 (11-12): 50-53.

- Hirshkind, Charles \& Mahmood, Saba (2002): Feminism, the Taliban, and Politics of CounterInsurgency, in: Anthropological Quarterly, 75 (2): 339-54.

. Hyndman, Jennifer (2003): Beyond Either/Or: A Feminist Analysis of September 11th, in:
ACME: An International E-Journal for Critical Geographies, 2 (1): 1-13. http://www.acm e-journal.org (accessed June 11, 2006).

- In the Name of Allah (u.d.). In the Name of Allah. http://www.inthenameofallah.net (accessed July 5, 2005).

- Jay, Gregory (2003): White Out: Race and Nationalism in American Studies, in: American Quarterly, 55 (4): 781-95.

- Joseph, Nicola (2002): 9-11, from a Different Perspective: Interview with Nawal El Sadaawi and Sherif Hetata, in: Women in Action (1). http:// www.isiswomen.org (accessed June 11, 2006). - Kammen, Michael (1993): The Problem of American Exceptionalism: A Reconsideration, in: American Quarterly, 45 (1): 1-43.

- Kaplan, Amy (2003): Violent Belongings and the Question of Empire Today: Presidential Address to the American Studies Association, October 17, 2003, in: American Quarterly, 56 (1): 1-18.

- Knickmeyer, Ellen (2002): Vice Creeps Back to Kandahar, in: Guardian Unlimited, February 22, 2002. http://www.guardian.co.uk (accessed June 11, 2006).

- Knippenberg, Joseph M. (2004): The Long and Winding Road: George W. Bush and the AfricanAmerican Churches (Editorial), in: Ashbrook Center for Public Affairs at Ashland University, October 2004. http://www.ashbrook.org (accessed August 23, 2005).

- Koshy, Susan (2001): Morphing Race into Ethnicity: Asian Americans and Critical Transformations of Whiteness, in: boundary, 2 (1): 153-94.

- Lerner, Sharon (2001): What Women Want: Feminists Agonize over War in Afghanistan, in: Village Voice, November 6, 2001, 53-55.

- Livingstone, Ken, et al. (2004): The Fight against Oppression and Islamophobia. (Letter), in: Guardian (London), September 30, 2004, 27. - Losurdo, Domenico (2004): Preemptive War, Americanism, and Anti-Americanism, in: Metaphilosophy, 35 (3): 365-85.

- Lunsing, Wim (2003): Islam Versus Homosexuality? Some Reflections on the Assassination of Pim Fortuyn, in: Anthropology Today, 19 (2): 19-21. - Luongo, Michael T. (2006): WorldPride: Notes from Jerusalem. August 12, 2006.

http://www.gay.com (accessed September 6, 2006).

- MacKinnon, Catherine A. (2002): State of Emergency, in: Women's Review of Books, 19 (6): 7-8. - Mahmood, Saba (2004): Politics of Piety: The Islamic Revival and the Feminist Subject. Princeton University Press: Princeton.

- Manji, Irshad (2005): America's Wild West (Op- 
Ed), in: Los Angeles Times, May 1, 2005. http:// www.latimes.com (accessed June 11, 2006).

- Marks, Alexandra (2001): In This War, American Women Shed Role as 'Doves.', in: Christian Science Monitor, November 6, 2001, 1.

- Massad, Joseph (2002): Re-Orienting Desire: The Gay International and the Arab World, in: Public Culture, 14 (2): 361-85.

- Mbembe, Achille (2003): Necropolitics. Translated by Libby Meintjes. In: Public Culture, 15 (1): 11-40.

- McClintock, Anne (1995): Imperial Leather: Race, Gender, and Sexuality. Routledge: New York.

- McWhorter, Ladelle (2003): Sex, Race, and Biopower: A Foucauldian Genealogy, in: Hypatia: A Journal of Feminist Philosophy, 19 (3): 38-62.

- Merom, Gil (1999): Israel's National Security and the Myth of Exceptionalism, in: Political Science Quarterly, 114 (3): 409-34.

- Miller, Elizabeth (2002): An Open Letter to the Editors of Ms. Magazine, in: Middle Eastern Affairs Conference, Pittsburg State University International Studies Program. April 20, 2002. http:// www.pittstate.edu (accessed June 11,2006).

- Minwalla, Framji (2003): Tony Kushner's Homebody/Kabul: Staging History in a Post-colonial World, in: Theater, 33 (1): 29-43.

- Mohanty, Chandra Talpade (1988): Under Western Eyes: Feminist Scholarship and Colonial Discourse, in: Feminist Review (30): 61-88.

- Morcos, Rauda (2004): Queering Palestinian Solidarity Activism. Posted June 6, 2004. http:// montages.blogspot.com (accessed June 12, 2006). - Mustikhan, Ahmar (2003): Group Fights for Palestinian Gays' Safety, in: PlanetOut News and Politics, April 4, 2003. http://www.planetout.com (accessed June 15, 2005).

- Najmabadi, Afsaneh (2005): Women with Mustaches and Men without Beards: Gender and Sexual Anxieties of Iranian Modernity. University of California Press: Berkeley.

- Nast, Heidi J. (2002): Queer Patriarchies, Queer Racisms, International, in: Special issue of Antipode: A Radical Journal of Geography, 34 (5): 874909.

- New York Times (2002): A Million Votes for Dead Man. May 22, 2002, Al4.

- NewsPlanet Staff. (1999a): Breaking News: London Bombing!, in: PlanetOut News and Politics, April 29, 1999. http://www.planetout.com (accessed June 12, 2006).

- NewsPlanet Staff. (1999b): London Gay Bar Bombed, in: PlanetOut News, April 30, 1999. http://www.planetout .com (accessed June 12, 2006).
- No Pride in Occupation (u.d.). No Pride in Occupation. www.nopridewithoutpalestinians.org (accessed June 12, 2006).

- OutRage! (2004): Muslim Cleric Says: Death to Gays and Jews. Press release. July 9, 2004.

www.outrage.nabumedia.com (accessed June 15, 2005; no longer available). Republished July 9, 2004. http://www.indymedia.org.uk (accessed June 12, 2006).

- OutRage! (2005a): Press Photos. http://outrage.nabumedia.com (accessed July 14, 2005; no longer available). Republished http://www.petertatchel.net (accessed June 12, 2006).

- OutRage! (2005b): Terrorist Danger to Gay Venues; 'Increase Security,' Urges OutRage! Press release. July 18, 2005. http://outrage.nabumedia.com (accessed 30 August 2005; no longer available). Republished July 26, 2005. http://haganah.org.il (accessed June 12, 2006).

- Patel, Geeta (2004): Homely Housewives Run Amok: Lesbians in Marital Fixes, in: Public Culture, 16 (1): 131-57.

- Pellegrini, Ann (2002): Commodity Capitalism and Transformations in Gay Identity, in: Arnaldo CruzMalave and Martin Manalansan IV (eds.): Queer Globalizations: Citizenship and the Afterlife of Colonialism. New York University Press: New York, 134-45.

- PlanetOut Network (2005) Amsterdam Police Vows to Contact Hate Crimes, in: PlanetOut News and Politics/June 10, 2005. http://www.planetout.com (accessed June 2006).

- Queer Jihad (2003): About Queer Jihad.

Updated January 10, 2003. http://www.well.com (accessed June 11, 2006).

- Queer Jihad (2005): Queer Jihad. Updated August 7, 2005. http://www.well.com (accessed June 11,2006 )

- Quinn, Andrew (2001): Gay Muslims Come Out in S.F. Pride Parade, in: PlanetOut News and Politics, June 25, 2001. http://www.planetout.com (accessed June 11, 2006).

- Rauchway, Eric (2002): More Means Different: Quantifying American Exceptionalism, in: Reviews in American History, 30 (3): 504-16.

- Reddy, Chandan (2005): Asian Diasporas, Neoliberalism, and Family: Reviewing the Case for Homosexual Asylum in the Context of Family Rights, in: Social Text, 23 (3-4): 101-19.

- Reynolds, Maura (2002): Kandahar's Lightly Veiled Homosexual Habits, in: Los Angeles Times, April 3, 2002. http://www.latimes.com (accessed June 11, 2006).

- Roy, Sandip (2005): Can Gay Marriage Protect Europe from Subway Bombers? July 13, 2005. 
http:// news.pacificnews.org (accessed July 14, 2005).

- Rowe, John Carlos (2004): Edward Said and American Studies, in: American Quarterly, 56 (1): 33-47.

- Scroggins, Deborah (2005): The Dutch-Muslim Culture War, in: Nation, June 27, 2005, 21-25.

. Sharma, Parvez (2004): Manufacturing Dissent, in: Center for Lesbian and Gay Studies (CLAGS)

Newsletter, fall 2004, 5.

- Sheffer, Doron \& Weiss, Efrat (2005): Violence Erupts at Gay Pride Parade. June 30, 2005. http://www.ynetnews.com (accessed June 12, 2006).

- Skier, Stephanie (2004): Western Lenses on Male Same-Sex Relationality in Pashtun Afghanistan, in: queer: 11-22. http://www.queer-journal.com (accessed June 11, 2006).

- Smeal, Eleanor (2001): Special Message from the Feminist Majority on the Taliban, Osama bin Laden, and Afghan Women. September 18, 2001. http://feminist.org (accessed June 11, 2006).

. Smith, Chris S. (2002): Kandahar Journal. Shh, It's an Open Secret: Warlords and Pedophilia, in: New York Times, February 21, 2002, A4.

- Smith, Rhonda (2002): More Acceptance for Gay Muslims Since 9/11, in: Washington Blade, April 5, 2002. Republished http://www.globalgayz.com (accessed June 11, 2006).

- Spivak, Gayatri Chakravorty (2004): Globalicities: Terror and Its Consequences, in: CR: The New Centennial Review, 4 (1): 73-94.

- Stephen, Chris (2002): Startled Marines Find Afghan Men All Made Up to See Them, in: Scotsman, May 24, 2002, 15.

- Stolba, Christine (2002): Feminists Go to War, in: Women's Quarterly, January 1, 2002, [intet sidetal].

- Stoler, Ann Laura (1995): Race and the Education of Desire: Foucault's History of Sexuality and the Colonial Order of Things. Duke University Press:

Durham.

- Sullivan, Andrew (2004): Decent Exposure. [Anmeldelse af The Trouble with Islam, af Irshad Manji], in: New York Times, January 25, 2004, sec. 7, p. 10.

- Tatchell, Peter (1995): The New Dark Ages: Peter Tatchell Documents the Global Threat of Islamic Fundamentalism. http://www.petertatchell.net (accessed June 12, 2006).

- Tatchell, Peter (1998): The Rise of Islamic Fundamentalism in Britain. Press release. April 10, 1998. http://outrage.nabumedia.com (accessed June 15, 2005; now unavailable).

- Thacker, Eugene (2005): The Global Genome: Biotechnology, Politics, and Culture. MIT Press: Cambridge, Massachusetts.

- Thobani, Sunera (2002): War Frenzy, in: Meridians: Feminism, Race, Transnationalism 2 (2002): 289-97.

- Wilcox, Barbara (2006): WorldPride Denied Parade Permit. July 21, 2006. http://www.gay .com (accessed September 6, 2006).

- Zeesil, Leah (2006): Jerusalem WorldPride Smaller Than Expected, in: Windy City Times, August 16, 2006. http://www.windycitytimes.com (accessed September 6, 2006).

. Zinn, Howard (2005): The Power and the Glory: Myths of American Exceptionalism, in: Boston Review: A Political and Literary Forum, 30 (3-4). http://bostonre view.net (accessed June 11, 2006). 